\title{
Implementing Monetary Policy after the 2008 Financial Crisis
}

\author{
Dr. Ioannis N. Kallianiotis \\ Economics/Finance Department, \\ The Arthur J. Kania School of Management, \\ University of Scranton

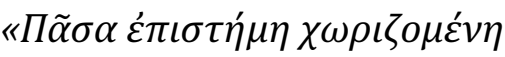

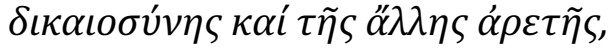

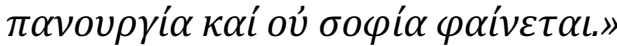

\section{$\Pi \lambda \alpha ́ \alpha \omega \nu$}

\begin{abstract}
Every six weeks or so (9 times during the year), the financial world watches as the Federal Open Market Committee (FOMC) decides on a target interest rate in the federal funds market for the next period. But what happens next? How do policymakers make sure that interest rates in the fed funds market trade within the target range? What will be the effect of the new target rate on the Wall Street and the Main Street? How efficient is so far the monetary policy after the latest global financial crisis? Is the target rate the correct one? The framework that the FOMC uses to implement monetary policy has changed over the last decade and continues to evolve today. Before the 2008 financial crisis, policymakers used one set of instruments to achieve the target rate. However, several policy interventions introduced soon after the crisis drastically altered the landscape of the federal funds market. This new and uncertain environment, with enormous reserves, necessitated a new set of instruments for monetary policy implementation. Lately, after December 2015, as the FOMC began to unwind the effects of these policy interventions, some questions arise: What rules will be followed by the Fed? What happens next as the federal funds market converges to a "new normal"? How effective will be the new policy? Can the Fed prevent a new crisis? The federal funds rate is very low and affects negatively the financial markets (bubbles are growing), the real rates of interest, and the deposit rates, which means the true economic welfare is falling and a new global recession is in preparation, if the latest easy money policy will continue.
\end{abstract}

Key Words: Monetary Policy, Central Banks and Their Policies, Money and Interest Rates, Financial Markets and the Macro-economy, Production, Economic Welfare

JEL (Classification): E52, E58, E4, E44, E23, D60

\section{MONETARY POLICY BEFORE THE 2008 FINANCIAL CRISIS}

Before the financial crisis, the federal funds market was an interbank market in which the largest players on both the demand and supply sides were domestic commercial banks, and in which rates were set bilaterally between the lending and borrowing banks. The main drivers of activity in this market were daily idiosyncratic liquidity shocks, along with the need to fulfill reserve requirements. Rates were set based on the quantity of funds available in the market and the perceived risk of the borrower, as follows:

$R_{R}=r_{R} D D$

$R_{R}^{d}=R_{R}^{s} \quad \Rightarrow i_{F F}^{e f f}$

$i_{F F}^{e f f}=f\left(R_{R}^{s}, \quad\right.$ Risk $)$ 
where, $R_{R}=$ required reserves, $r_{R}=$ required reserves ratio, $D D=$ demand deposits (transaction accounts), $R_{R}^{d}=$ demand for reserves, $R_{R}^{s}=$ supply of reserves, $i_{F F}^{e f f}=$ effective federal funds rate.

Although the Federal Open Market Committee (FOMC) sets a target for the federal funds rate ( $\left.\bar{i}_{F F}\right)$, the actual funds rate is determined in the market, with the "effective" rate $\left(i_{F F}^{e f f}\right)$ being the weighted average of all the overnight lending transactions in the federal funds market. When the effective rate moved too far from the Fed's target before the financial crisis, the FOMC adjusted it through open market operations. For example, if the Fed wanted to raise the effective rate, it would sell securities to banks in the open market and banks reserves are falling. Buying those securities by the banks reduced the funds banks had available for lending in the federal funds market and drove the interest rate up. The Fed's portfolio of securities consisted mainly of treasury bills, generally of short maturity, and its balance sheet was small. (Graph 1 and Figure 1). ${ }^{1}$

${ }^{1}$ Graph 1: All Federal Reserve Banks: Total Assets:

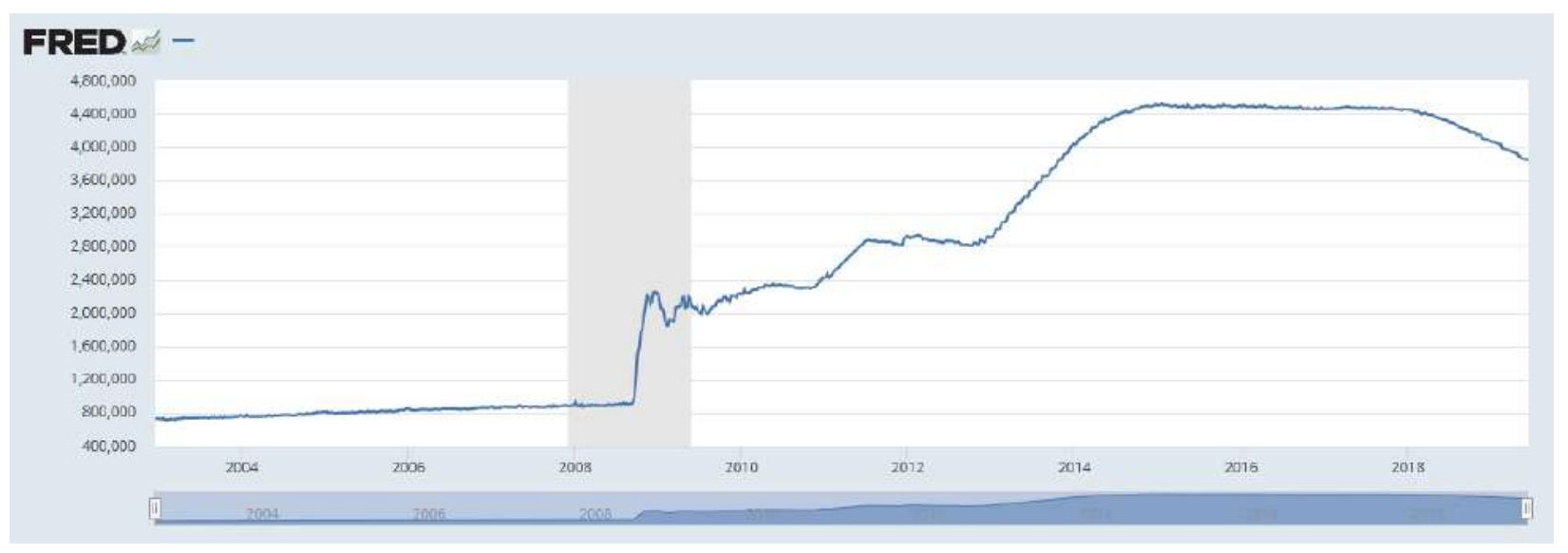

Note: Total assets were on September 10, 2008: \$925.725 billion; December 31, 2008: \$2,239.457 billion; May 19 , 2010: $\$ 2,350.890$ billion; February 1, 2012: $\$ 2,924.947$ billion; January 14, 2015: $\$ 4,516.077$ billion; and on June 13, 2019: $\$ 3,849.955$ billion. Today (9/4/2019), they were $\$ 3,761.508$ billion.

Source: https://fred.stlouisfed.org/series/WALCL

Figure 1: The Fed's Balance Sheet. 
Banks hold reserves in an account at the Fed and are required to maintain a balance above a certain fraction of their deposits, called required reserves (RR).2 Prior to the onset of the Great

\section{Figure 1. The Fed's Balance Sheet}

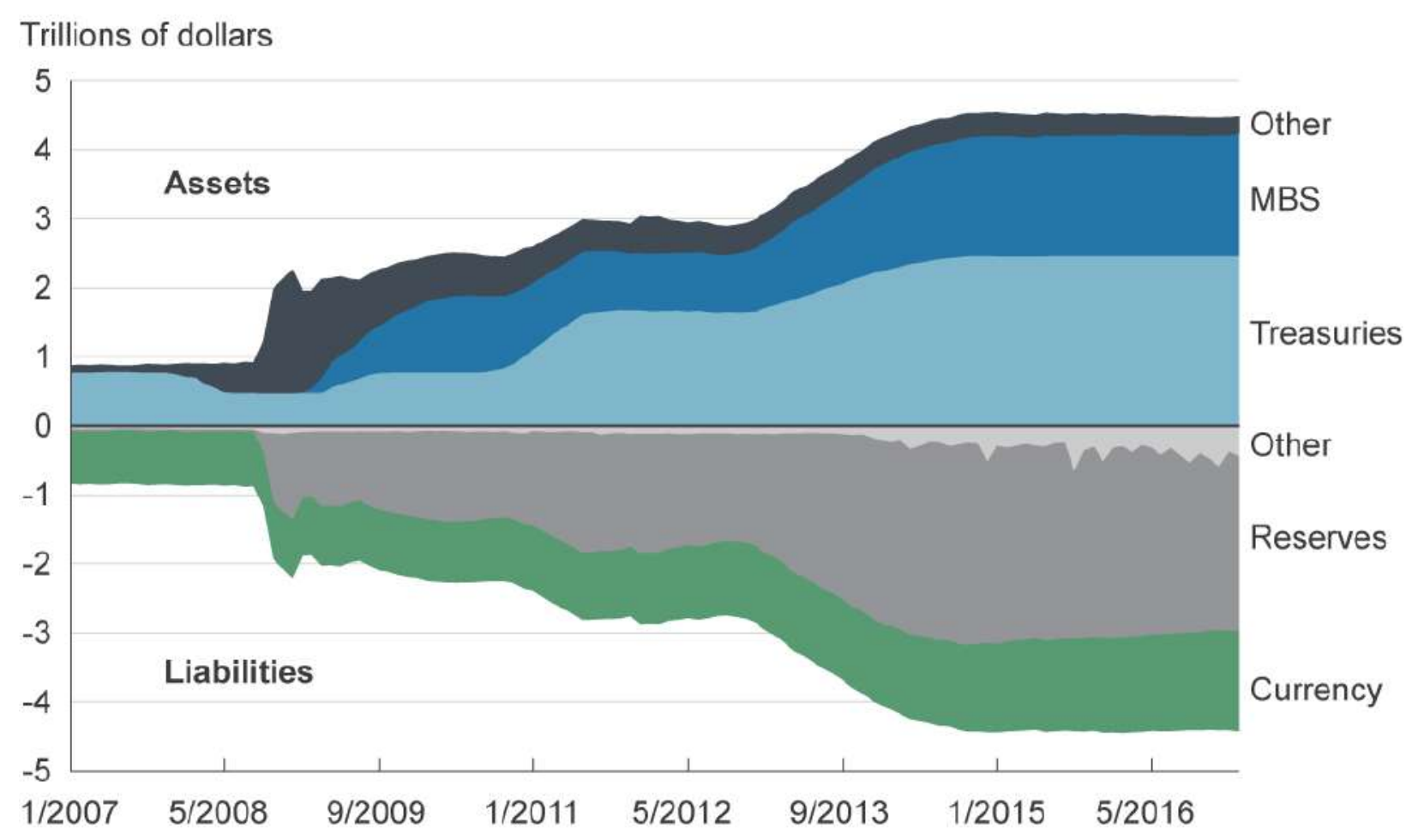

Source: Board of Governors of the Federal Reserve System.

${ }^{2}$ Although not all banks are depository institutions, and not all depository institutions are banks, we will use "bank" to refer to depository institutions trading in the fed funds market, including bank holding companies, standalone commercial banks, and thrifts. However, institutions other than banks also trade in the federal funds market. Under current regulation, once deposits exceed a minimal threshold, these banks are required to hold at least $10 \%$ of any additional deposits as reserves at the Fed. $\left(R_{R}=r_{R} D D\right)$.

\section{Reserve Requirements}

\section{Liability Type}

Net transaction accounts $\underline{1}$

$\$ 0$ to $\$ 16.3$ million 2

More than $\$ 16.3$ million to $\$ 124.2$ million 3

More than $\$ 124.2$ million

Nonpersonal time deposits

Eurocurrency liabilities

\section{Requirement \\ \% of liabilities}

0

3

10

0

0
Effective date

1-17-19

1-17-19

$1-17-19$

$12-27-90$

$12-27-90$

Source: https://www.federalreserve.gov/monetarypolicy/reservereq.htm 
Recession in January 2008 (Graph 2), ${ }^{3}$ a defining feature of the fed funds market was that reserves were scarce. As a result, throughout the day a bank's reserves would fluctuate as payments were made or received, and some banks would find themselves short of their reserve requirements at the end of the day. In order to avoid borrowing at the Fed's discount window, these banks would look to borrow from other banks in the fed funds market. ${ }^{4}$

At the same time, some other banks would find themselves holding excess reserves at the end of the day $\left(\mathrm{R}_{\mathrm{E}}\right)$. Since the Fed did not pay interest on excess reserves deposited overnight, these banks would look to lend in the federal funds market to earn a positive rate of return. As there were a significant number of banks on both sides of the market, some looking to borrow and others looking to lend; trading volume in the fed funds market was substantial, and interbank trades dominated market activity. Afonso, Entz, and LeSueur $(2013)^{5}$ estimated an average daily trading volume of approximately $\$ 200$ billion in the fourth quarter of 2006 , of which approximately $60 \%$ was accounted for by bank-to-bank lending. (Graph 3). ${ }^{6}$

3 Graph 2: United States GDP Growth Rate:

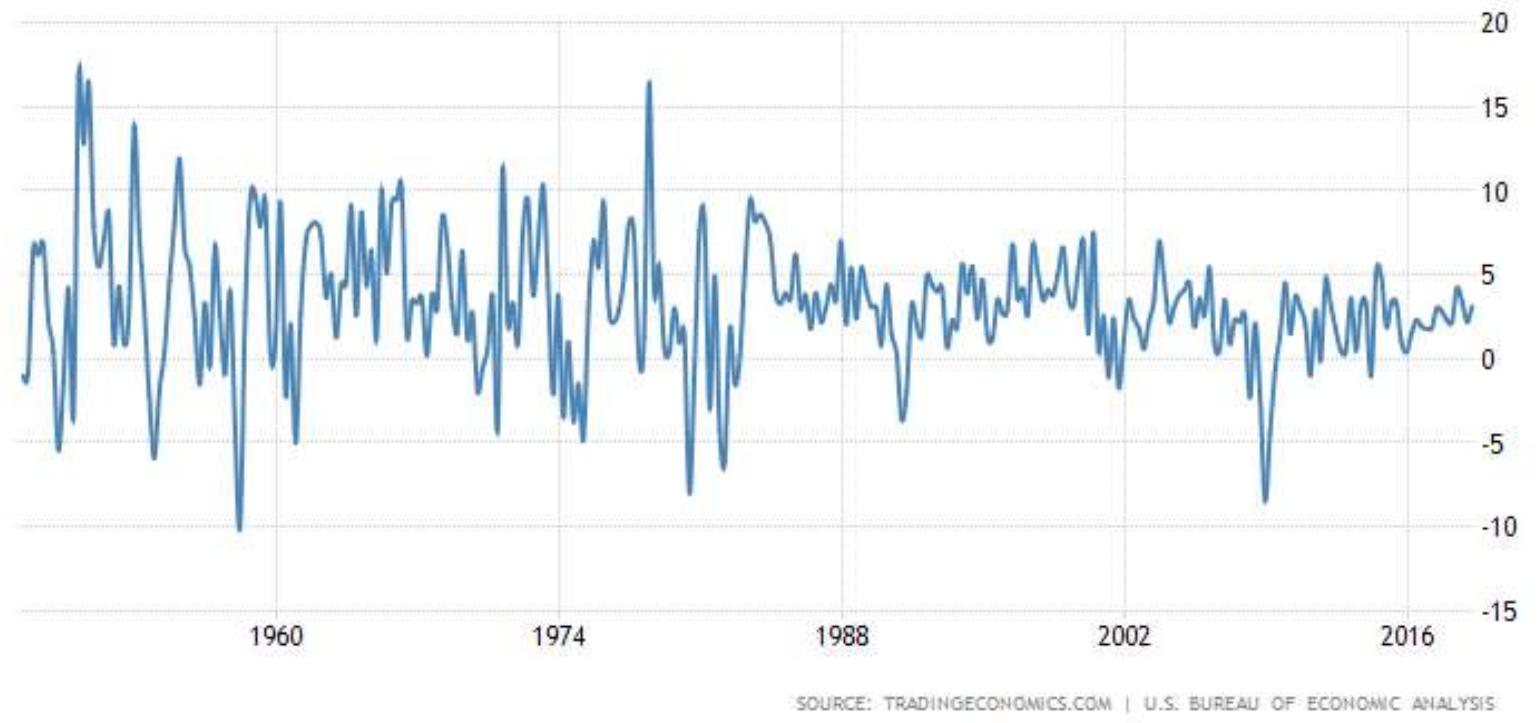

Source: https://tradingeconomics.com/united-states/gdp-growth

${ }^{4}$ Banks would try to avoid borrowing at the discount window because the rate was higher than the typical rate being offered in the fed funds market (with June 26, 2019, they were: $i_{D R}=3.00 \%>i_{F F}^{e f f}=2.39 \%$. See, The Wall Street Journal, June 27, 2019, p. B9), and because there was a stigma associated with borrowing at the discount window. See Ennis and Weinberg (2013).

5 See, "Who's Borrowing in the Fed Funds Market?", https://libertystreeteconomics.newyorkfed.org/2013/12/whos-borrowing-in-the-fed-funds-market.html ${ }_{6}$ Graph 3: Fed Funds Lending (2006-2012) in billions of dollars: 
In this environment of scarce reserves, monetary policy implementation was fairly straightforward. The Open Market Trading Desk (the "Desk") at the Federal Reserve Bank of New York would implement the desired target for the effective federal funds rate (EFFR) by adjusting the supply of reserves via open market operations.7 If the Desk wanted to increase market rates, it would sell securities (such as Treasury bills) in the market, there-by increasing

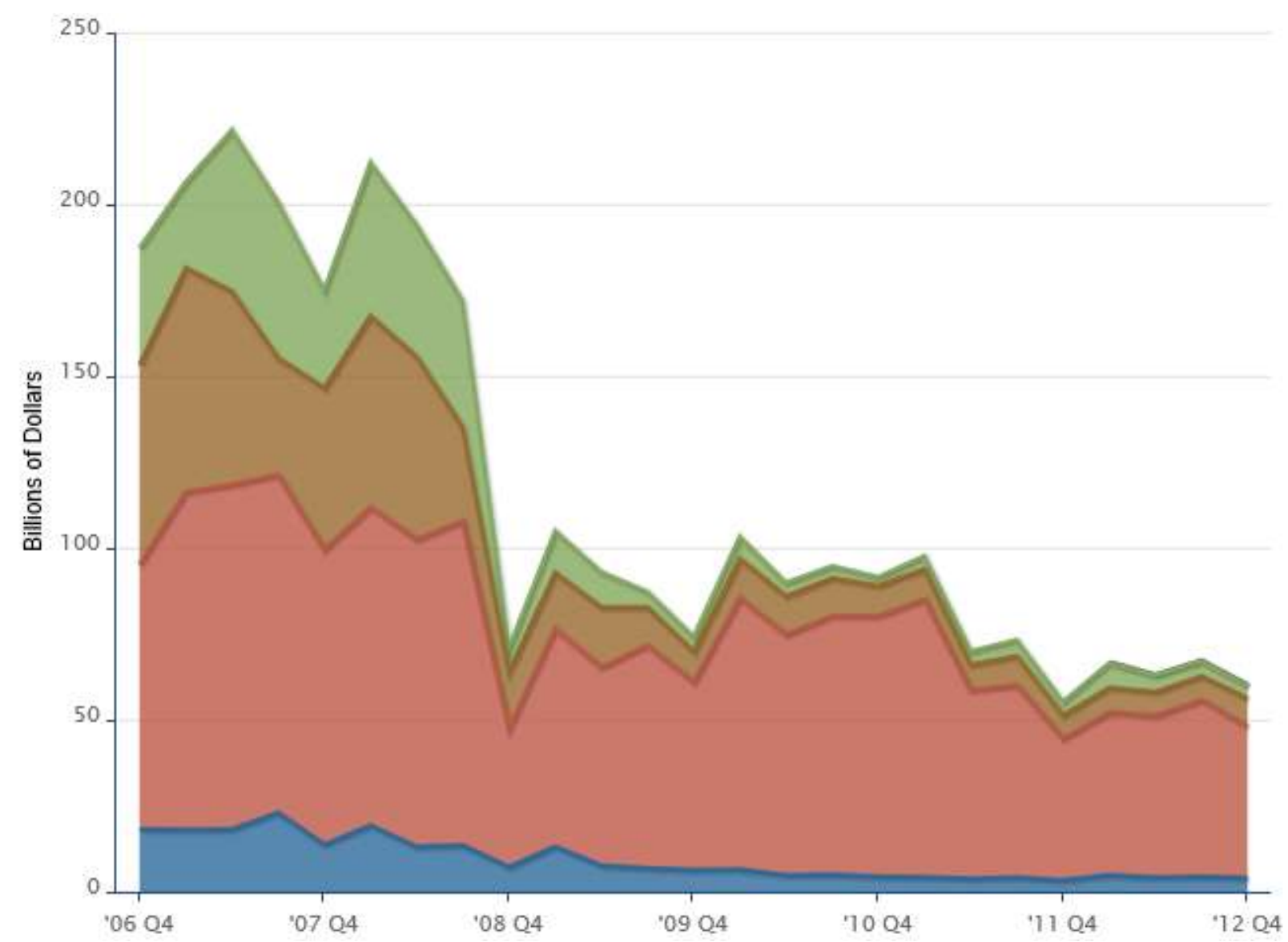

Note: For 2007:Q2, the Lending was the highest: Foreign Entities (green): \$47.0 billion (21.2\%); Domestic Bank Holding Companies (brown): \$56.2 billion (25.3\%); Federal Home Loan Banks (red): \$100.4 billion (45.3\%); Domestic Standalone Banks (blue): $\$ 18.2$ billion (8.2\%); Total $\$ 221.70$ billion.

For 2008:Q4, the lending has declined drastically, the Lenders were: Foreign Entities (green): $\$ 6.9$ billion (9.7\%); Domestic Bank Holding Companies (brown): \$16.5 billion (23.3\%); Federal Home Loan Banks (red): \$40.3 billion (56.7\%); Domestic Standalone Banks (blue): $\$ 7.3$ billion (10.3\%); Total $\$ 71.03$ billion.

For 2012:Q4, the Lenders have declined, too: Thrifts: $\$ 0.4$ billion; Foreign Entities (green): $\$ 3.5$ billion (5.8\%); Domestic Bank Holding Companies (brown): $\$ 8.2$ billion (13.6\%); Federal Home Loan Banks (red): $\$ 44.0$ billion (73.0\%); Domestic Standalone Banks (blue): $\$ 4.2$ billion $(0.07 \%)$; Total $\$ 60.28$ billion.

Source: https://www.newyorkfed.org/fed-funds-lending/index.html

7 See, "Open Market Operations in the 1990s".

https://www.federalreserve.gov/pubs/bulletin/1997/199711lead.pdf. See also, Kallianiotis (2017). If a bank cannot find a lender, it can borrow from the Fed directly at the discount window rate. Now (8/30/2019), the $i_{D R}=2.75 \%>i_{F F}^{e f f}=2.12 \%$. See, The Wall Street Journal, September 4, 2019, p. B9. 
the supply of securities and decreasing the supply of cash held by banks. (Figure 2). ${ }^{8}$ As banks' supply of cash became scarcer, the rate at which they would be willing to lend would rise. Hence, as in the usual model of supply and demand, a reduction in the supply of reserves in the market would lead to an increase in the fed funds rate, eq. (3). As the fed funds rate rose, market rates would rise as well. The Federal Open Market Committee (FOMC) did not achieve the desired rate directly; instead, it used supply and demand for reserves to achieve a rate

8 Figure 2: Cash Assets by Type of Bank

\section{Figure 2. Cash Assets by Type of Bank}

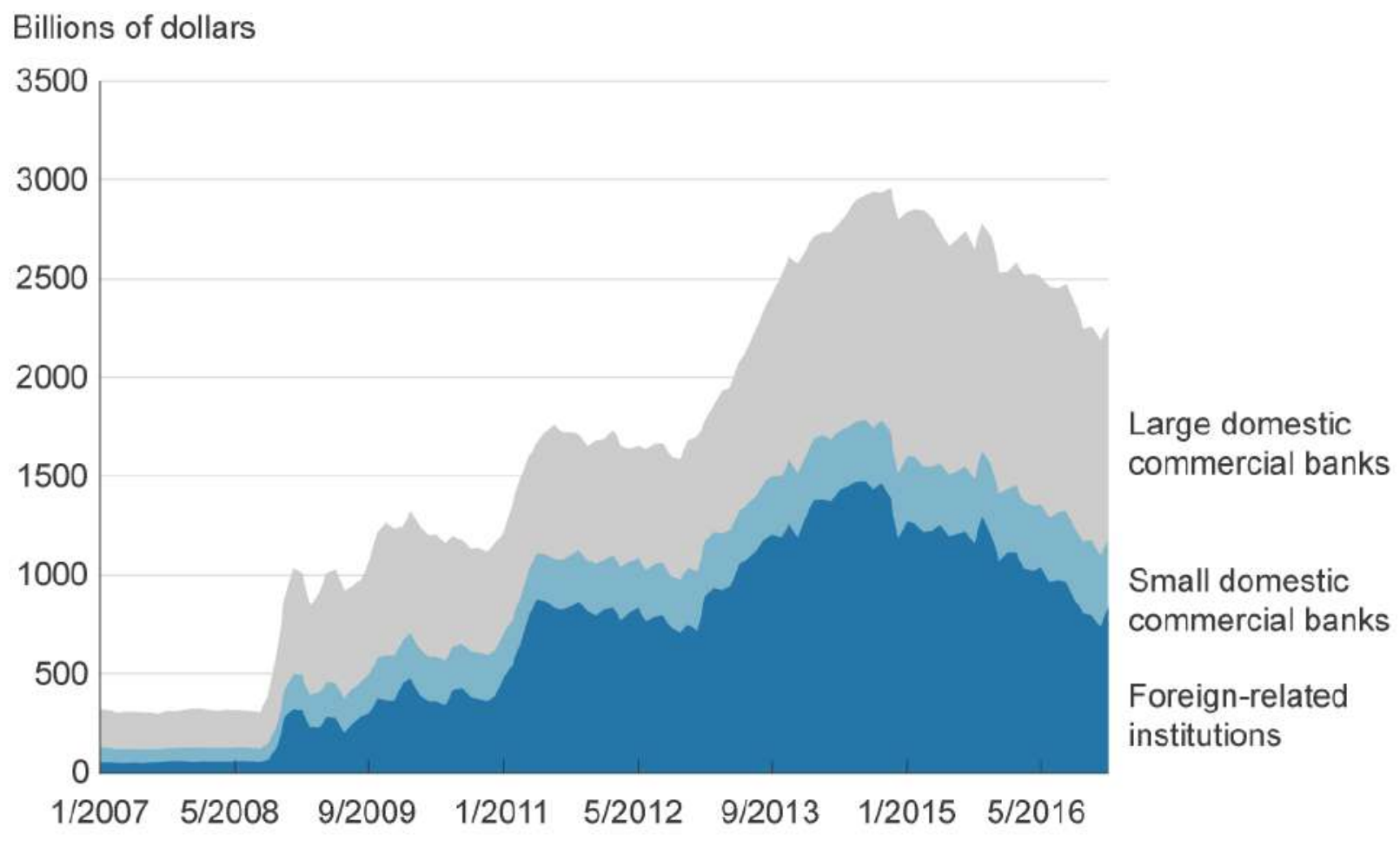

Note: Cash assets include vault cash, cash items in the process of collection, balances due from depository institutions, and balances due from Federal Reserve Banks.

Source: Board of Governors of the Federal Reserve System. 
within the target range (i.e., from $0.00 \%-0.25 \%$; lately, from: $2.25 \%-2.50 \%$, and it became on July 31, 2019: 2.00\%-2.25\%), ${ }^{9}$ Graph 4.

A high fed funds rate means banks will borrow less. That is because it costs more to borrow enough fed funds to meet the reserve requirement. Interest rates will be high as a result. A low fed funds rate means banks will borrow more. This allows them to charge a lower interest rate. Banks can also borrow from the Federal Reserve's discount window, ${ }^{10}$ which interest rate, known as the Federal discount rate, ${ }^{11}$ is usually $0.50 \%$ higher. That encourages banks to borrow fed funds from each other. At the end of each day, banks with reserves more than the requirement, lend them to banks that are short. The borrower can hold the funds in its vaults or at a Federal Reserve Bank. Either way, it counts to meet the bank's reserve requirement. The lending bank is engaged in a fed funds sale. Similarly, the borrowing bank is making a fed funds purchase.

The reserve requirement does not apply to small banks, those with net transactions of $\$ 16.3$ million or less (see, footnote 2). They ordinarily have a relationship with a larger bank to lend it the amount it needs. That gives the smaller bank a bit of a competitive advantage because it can earn extra interest on its funds. The fed funds market has been shrinking ever since

${ }^{9}$ Graph 4: Federal Funds Data:

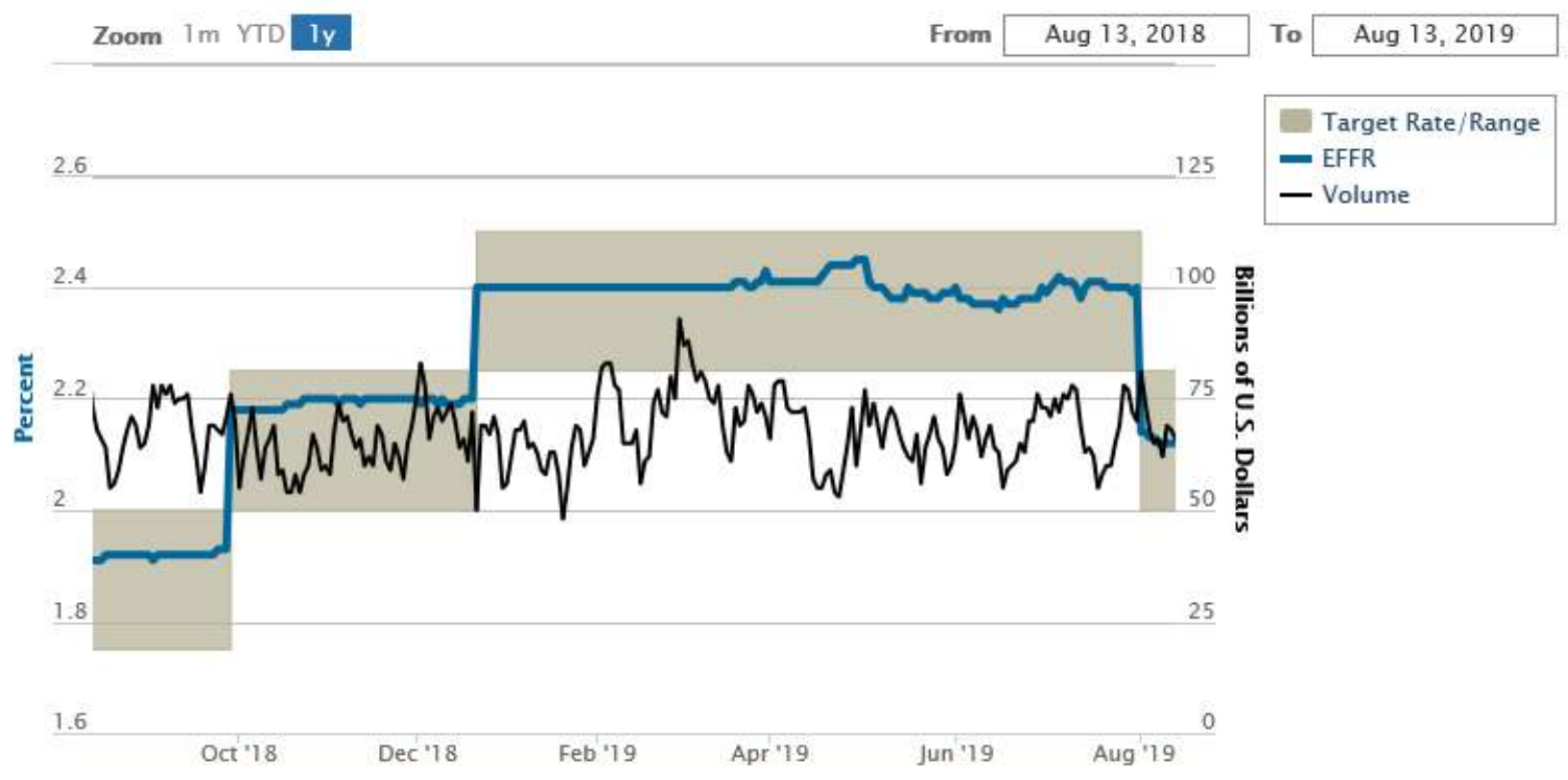

Source: https://apps.newyorkfed.org/markets/autorates/fed\%20funds .

"Nearly half of the Fed's 12 reserve bank presidents said they didn't see a convincing case to cut interest rates in the run-up to last month's policy meeting. Two of them, Boston's Eric Rosengren and Kansas City's Esther George, had a vote and dissented from the decision to lower the policy rate by a quarter percentage point, to a range between $2 \%$ and $2.25 \%$. At the same time, there wasn't much support for a larger, half-point rate cut at the meeting. Mr. Powell characterized the rate cut as a 'mid-cycle adjustment' and said it wasn't the start of a 'long cutting cycle' of the type the Fed adopts in a recession or severe downturn." See, "Fed Minutes to Show Extent of Committee Divisions on Last Month's Rate Cut", https://www.wsj.com/articles/fed-minutes-to-show-extent-ofcommittee-divisions-on-last-months-rate-cut-11566379803

10 See, Kimberly Amadeo, "Federal Reserve Discount Window and How It Works", https://www.thebalance.com/federal-reserve-discount-window-3305923

11 The discount rate is: $i_{D R}=i_{F F}^{e f f}+0.50 \%$. See, Kimberly Amadeo, "Federal Reserve Discount Rate", https://www.thebalance.com/federal-reserve-discount-rate-3305922 
the 2008 financial crisis. ${ }^{12}$ In 2007, banks lent $\$ 222$ billion. In 2012, it was only $\$ 60$ billion, (Graph 3). What happened? First, the Federal Reserve increased its balance sheet to $\$ 4$ trillion through quantitative easing, ${ }^{13}$ (Figure 1 and Graph 1). On December 18, 2013: it was $\$ 4,008.062$ billion. The Fed bought U.S. Treasurys and mortgage-backed securities ${ }^{14}$ from banks. ${ }^{15}$ That left them with lots of reserves on their balance sheets. Second, the Fed now pays banks interest on excess reserves. ${ }^{16}$ Banks have less incentive to lend excess fed funds. ${ }^{17}$ The Federal Reserve sets the reserve requirement in order to control the amount of money available to lend. That is known as liquidity. ${ }^{18}$ The requirement keeps banks from lending out all their money. The Fed requires that a certain percentage of the bank's deposits need to be reserved each night.

Thus, before the financial crisis, the federal funds market was a market in which domestic commercial banks with excess reserves would lend funds overnight to other commercial banks with temporary shortfalls in liquidity. What has happened to this market since the financial crisis? Though the banking system has been awash (flooded) in reserves and the federal funds rate has been near zero, the market has continued to operate, but it has changed. Different institutions now participate. Government-sponsored enterprises such as the Federal Home Loan Banks (FHLB) loan funds, and foreign commercial banks borrow, (Graph 3).

\section{THE FEDERAL RESERVE AND ITS NEW MONETARY POLICY TOOLS}

The financial crisis and the policies enacted to deal with its consequences led to great change in the federal funds market. In general, three developments caused most of the change: the Fed's balance sheet expanded in size, new banking regulations were enacted, and the Fed began paying interest to banks on funds they held in their reserve accounts at the Fed. Also, they started using new monetary policy tools.

The Federal Reserve utilizes four tools plus some new facilities of implementing monetary policy and to manage short-term interest rates: (1) Open market operations, $0 M 0,{ }^{19}$ (2) the discount rate, $i_{D R},{ }^{20}(3)$ reserve requirements, $\mathrm{R}_{\mathrm{R}}$ (reserve requirements ratio, $\left.r_{R}\right),{ }^{21}(4)$

\footnotetext{
12 See, Kimberly Amadeo, “2008 Financial Crisis: The Causes and Costs of the Worst Crisis Since the Great Depression", https://www.thebalance.com/2008-financial-crisis-3305679

13 See, Kimberly Amadeo, "Quantitative Easing Explained: How Central Banks Create Massive Amounts of Money", https://www.thebalance.com/what-is-quantitative-easing-definition-and-explanation-3305881 14 See, Kimberly Amadeo, "Mortgage-Backed Securities, Their Types, and How They Work: How MortgageBacked Securities Worked Until They Didn't", https://www.thebalance.com/mortgage-backed-securitiestypes-how-they-work-3305947

15 With June 27, 2019, the U.S. Treasury securities were: $\$ 2,110.193$ billion, the Mortgage-backed securities: $\$ 1,532.956$ billion, and other: $\$ 232.705$ billion. A total of $\$ 3,882.854$ billion. With August 8,2019 , there was a little reduction; the U.S. Treasury securities were: $\$ 2,080.703$ billion, the Mortgage-backed securities: $\$ 1,511.775$ billion, and other: $\$ 236.191$ billion. A total of $\$ 3,828.669$ billion.

https://www.federalreserve.gov/releases/h41/current/h41.htm

16 See, Interest on depository institutions' required and excess reserve balances. https://www.federalreserve.gov/monetarypolicy/20081006a.htm

17 See, "Who's Lending in the Fed Funds Market?",

https://libertystreeteconomics.newyorkfed.org/2013/12/whos-lending-in-the-fed-funds-market.html\#. Also see, Graph 3: Total Federal Funds Sold (Lending).

18 See, Kimberly Amadeo, "Liquidity, Its Gluts, Traps, and Ratios, and How the Fed Manages It: How It Controls the Economy and Your Finances", https://www.thebalance.com/liquidity-definition-ratios-how-itsmanaged-3305939

${ }^{19}$ See, "Open Market Operations”, https://www.newyorkfed.org/aboutthefed/fedpoint/fed32.html

20 See, "The Discount Window", https://www.newyorkfed.org/aboutthefed/fedpoint/fed18.html

21 See, "Reserve Requirements", https://www.federalreserve.gov/monetarypolicy/reservereq.htm . See also,
} 
interest on required and excess reserves, IOR\&ER, ${ }^{22}$ (5) overnight reverse repurchase agreement facility, ON RRP, ${ }^{23}(6)$ term deposit facility, TDF, ${ }^{24}$ and (7) expired policy tools. ${ }^{25}$ Using these tools (instruments), the Federal Reserve influences the demand for, and supply of, balances that depository institutions hold at Federal Reserve Banks. The interest rate on fed funds transactions is typically sensitive to the level of reserve balances in the banking system, [eq. (3)], and so changes made through these tools influences the fed funds rate. Fed funds transactions neither increase nor decrease total reserves [eq. (4)], rather they redistribute reserves by using Fed-wire Funds services.

$R_{T}^{d}=R_{R}+R_{E}=r_{R} D D+R_{E} \equiv R_{T}^{s}=R_{B}+R^{*}$

where, $R_{T}^{d}=$ demand for total reserves, $R_{R}=$ required reserves, $R_{E}=$ excess reserves, $r_{R}=$ required reserves ratio, $D D=$ demand deposits, $R_{T}^{S}=$ supply of total reserves, $R_{B}=$ borrowing reserves, and $R^{*}=$ non-borrowing reserves.

At the directive of the FOMC, the trading desk at the New York Fed ("the Desk") adjusts the level of reserve balances in the banking system through open market operations. In fact, the directive for implementation of U.S. monetary policy from the FOMC to the New York Fed states that the Desk should "create conditions in reserve markets" that will encourage fed funds to trade at a particular level. In formulating monetary policy, the FOMC sets a target level or range for the fed funds rate (currently, 2.00\% - 2.25\%) ${ }^{26}$ appropriate for the desired level of monetary policy accommodation. When rates approach zero, the FOMC may utilize other indicators of the stance of monetary policy in addition to the fed funds target. It is important to remember that actual fed funds rates $\left(i_{F F}^{e f f}\right)$ are determined by market participants, based on market conditions, eq. (3) above.

Lately, the Federal Reserve officials are weighing whether to use a new tool that could reduce the risk of a credit crunch in a downturn. The tool is known as the countercyclical capital

Kallianiotis (2017).

22 See, "Interest on Required Reserve Balances and Excess Balances",

https://www.federalreserve.gov/monetarypolicy/reqresbalances.htm

${ }^{23}$ See, Overnight Reverse Repurchase Agreement Facility,

https://www.federalreserve.gov/monetarypolicy/overnight-reverse-repurchase-agreements.htm

24 In the Policy Normalization Principles and Plans adopted by the Federal Open Market Committee (FOMC) on September 17, 2014, the FOMC indicated that during the process of monetary policy normalization, the Federal Reserve intends to use other supplementary tools, such as the TDF, as needed to help control the federal funds rate and move it into the target range set by the FOMC. See, Term Deposit Facility,

https://www.federalreserve.gov/monetarypolicy/tdf.htm

${ }^{25}$ During the financial crisis, the Federal Reserve established several facilities to provide liquidity directly to borrowers and investors in key credit markets. As the performance of financial markets has improved, the Federal Reserve has wound down some of the programs. They were the followings:

Money Market Investor Funding Facility

ABCP MMMF Liquidity Facility

Commercial Paper Funding Facility

Primary Dealer Credit Facility

Term Securities Lending Facility

Term Auction Facility

Term Asset-Backed Securities Loan Facility

Maturity Extension Program and Reinvestment Policy

See, "Expired Policy Tools", https://www.federalreserve.gov/monetarypolicy/expiredtools.htm

26 This new target was introduced on Wednesday, July 31, 20019 and it was a reduction by $0.25 \%$ from the previous rate, which was between of $2.25 \%-2.50 \%$. 
buffer. ${ }^{27}$ It allows the Fed to require banks to hold more loss-absorbing capital should the economy show signs of overheating, or to keep less of it during bad economic times. The buffer applies generally to banks with more than $\$ 250$ billion in assets, including firms such as JPMorgan Chase \& Co., Bank of America Corp. and Citigroup Inc. ${ }^{28}$ Unfortunately, there is an important monetary policy tool, which is inactive for a very long time. This is the margin requirements, $r_{m} .{ }^{29}$

\section{RECENT CHANGES IN MONETARY POLICY}

Although monetary policy has focused on setting an appropriate level for the federal funds rate since well before the financial crisis; but, the mechanics since the crisis have changed. In response to the crisis, several new policies were enacted (i.e., Quantitative Easing, QE) that altered the structure of the federal funds market in profound ways. On the borrowing side, the Fed's large-scale asset purchases (LSAPs) flooded the banking system with liquidity and made it less necessary to borrow or to seek more deposits. Banks have a deposit rate closed to zero ( $i_{D}=0.05 \%$ ) for eleven years. In addition, the Federal Deposit Insurance Corporation (FDIC) introduced new capital requirements ${ }^{30}$ that increased the cost of wholesale funding for domestic financial institutions. On the lending side, the Federal Reserve now pays some financial institutions interest on their excess reserves (IOER), ${ }^{31}$ which exceeds the federal funds rate. (Figure 3 and Footnotes 36-37). ${ }^{32}$ When institutions have access to this low-risk alternative, they have less incentive to lend in the federal funds market, because $i_{I O R}>i_{F F}^{\text {eff }}$.

\footnotetext{
${ }^{27}$ See, “Countercyclical capital buffer (CCyB)", BIS, https://www.bis.org/bcbs/ccyb/. See also, Occhino (2018). "Are the New Basel III Capital Buffers Countercyclical? Exploring the Option of a Rule-Based Countercyclical Buffer", https://www.clevelandfed.org/newsroom-and-events/publications/economic-commentary/2018economic-commentaries/ec-201803-countercyclical-capital-buffers.aspx
}

${ }^{28}$ See, "Fed Considers New Tool for a Downturn", https://www.wsj.com/articles/fed-considers-new-toolfor-a-downturn-11565614800?mod=article inline

${ }^{29}$ See, Kallianiotis (2017).

30 On April 16, 2019, the FDIC, the Office of the Comptroller of the Currency, and the Board of Governors of the Federal Reserve System issued a proposal that would establish risk-based categories for determining applicability thresholds for regulatory capital requirements for certain U.S. subsidiaries of foreign banking organizations and application of liquidity requirements to foreign banking organizations, certain U.S. depository institution holding companies, and certain depository institution subsidiaries. Comments on the proposal must be received by June 21, 2019. See, "Regulatory Capital", https://www.fdic.gov/regulations/capital/capital/index.html

${ }^{31}$ See, George Selgin, "The Strange Official Economics of Interest on Excess Reserves", Alt-M, October 3, 2017. https://www.alt-m.org/2017/10/03/strange-official-economics-of-interest-on-excess-reserves/

32 Figure 3: Federal Funds Rates. 
In this environment, the institutions willing to lend in the federal funds market are institutions whose reserve accounts at the Fed are not interest-bearing. These include governmentsponsored entities (GSEs) such as the Federal Home Loan Banks (FHLBs). The institutions willing to borrow are institutions that do not face the FDIC's new capital requirements and do have interest-bearing accounts with the Fed. These include many foreign banks. As such, the federal funds market has evolved into a market in which the FHLBs lend to foreign banks, which then arbitrage the difference between the federal funds rate and the rate on IOER (Graph 11).

Between January 2008 and the end of the financial crisis in June 2009, the Federal Reserve's balance sheet increased by $130 \%$, swelling to $\$ 2.1$ trillion (Graph 1 and Figure 1). Since then, the balance sheet has increased by an additional $\$ 2.3$ trillion and by July 2014 , it had become $\$ 4.4$ trillion. It consisted of $\$ 2.46$ trillion in treasuries, $\$ 26.81$ billion in agency debt, and $\$ 1.76$ trillion in mortgage-backed securities. The highest value was on January 14, 2015: $\$ 4.516$ trillion and today $(8 / 29 / 2019)$, it is $\$ 3.760$ trillion.

Thus, the landscape of the federal funds market was altered dramatically following the financial crisis. First, and most important, the Fed's large-scale asset purchase programs left depository institutions swimming inside excess reserves. Over four rounds of "quantitative easing" (QE) in 2008, 2010, 2012, and 2014, the Fed purchased assets such as U.S. Treasury debt and agency mortgage-backed securities (Graph 5 and Graph 1). ${ }^{33}$ As the Fed was buying

\section{Figure 3. Federal Funds Rates}

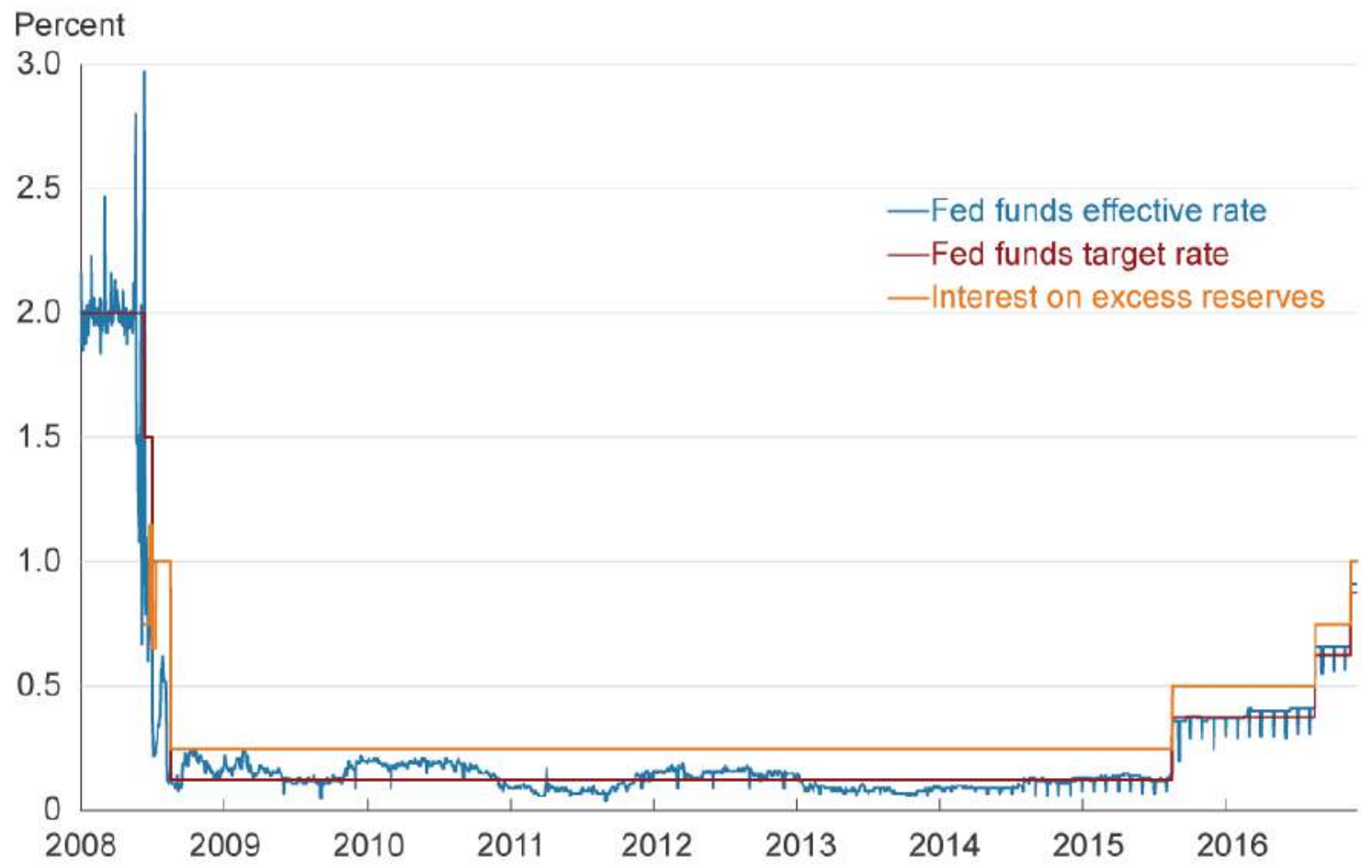

Source: Board of Governors of the Federal Reserve System.

${ }^{33}$ Graph 5: St. Louis Adjusted Monetary Base: 
these assets, the banks that were selling them saw their excess reserve balances to become enormous. As a result, excess reserves held by depository institutions reached $\$ 2,699.968$ billion by August 2014. To put that in perspective, in the pre-crisis years, by August 2008 they were $\$ 1.876$ billion; in December 2008 became $\$ 767.319$ billion; in February 2010 were $\$ 1,161.852$ billion; in July 2011 became \$1,618.118; in August 2014 they reached $\$ 2,699.968$ billion; and then, they started to decline and were in May 2019: \$1,376.568 billion. (Graph 6). ${ }^{34}$ Today (July 2019), they were $\$ 1,378.447$ billion.

Also, the average maturity of assets on the Fed's balance sheet rose as the FOMC rebalanced the portfolio, substituting long-term assets for short-term ones. Interest rates were also expected to stay low because this was the goal of policy suggested in FOMC post-meeting statements, policymaker speeches, and Congressional testimony. ${ }^{35}$ In October 2008, the Federal Reserve had begun to pay interest on reserves (IOR). ${ }^{36}$ The IOR was set at the top of

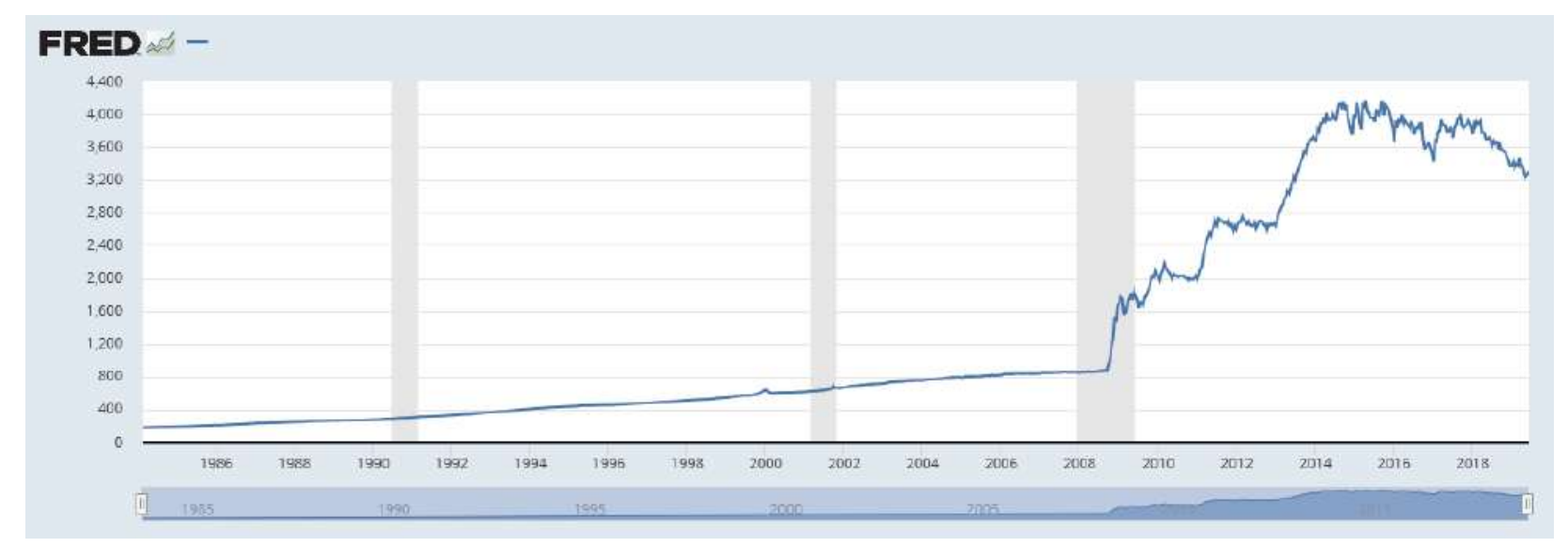

Note: Monetary base was on September 10, 2008: $\$ 874.83$ billion; December 31, 2008: \$1,690.829 billion; February 24, 2010: \$2,183.734 billion; February 22, 2012: \$2,753.052 billion; September 17, 2014: $\$ 4,149.829$ billion; April 15, 2015: \$4,167.780 billion; and on June 14, 2019: \$3,304.252 billion. Today (8/28/2019), it was $\$ 3,269.512$ billion.

Source: https://fred.stlouisfed.org/series/BASE/

${ }^{34}$ Graph 6: Excess Reserves of Depository Institutions:

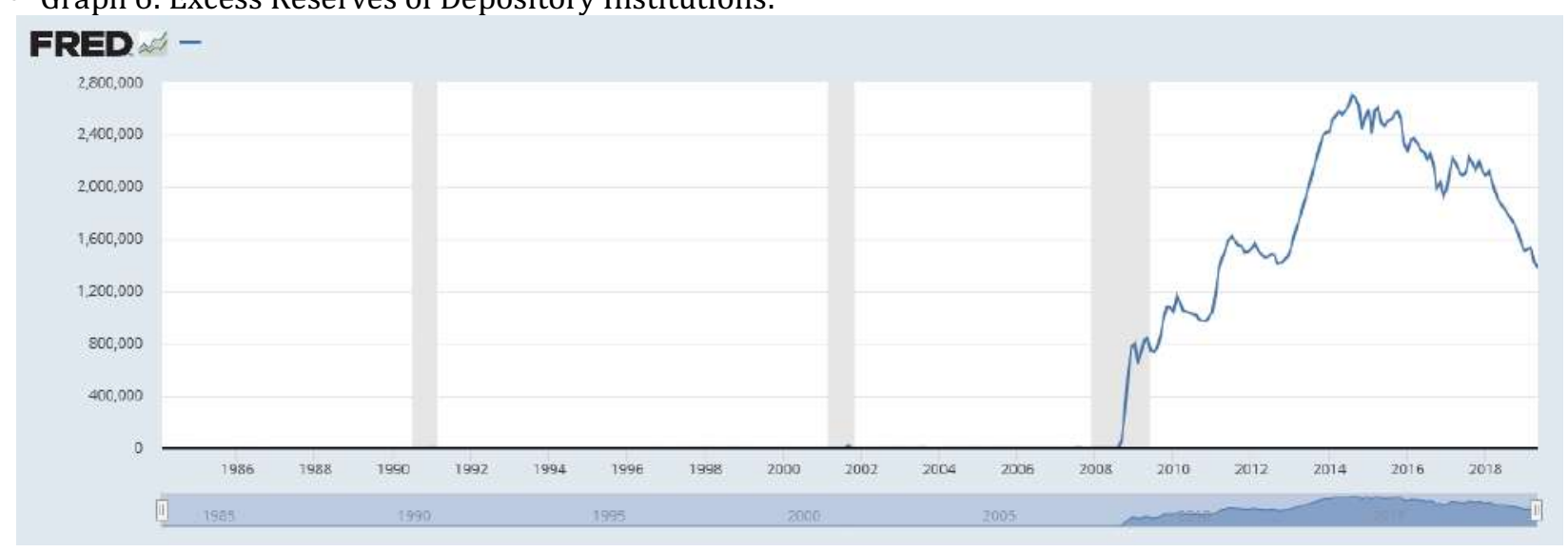

Source: https://fred.stlouisfed.org/series/EXCSRESNS

35 See, Potter (2017).

36 Interest on reserves (IOR) is the rate at which the Federal Reserve Banks pay interest on reserve balances, which are balances held by depository institutions at their local Reserve Banks. One component of IOR is Interest on Required Reserves (IORR), which is the rate at which the Federal Reserve Banks pay interest on required reserve balances $\left(R_{R}\right)$. Paying interest on required reserves aims to eliminate the opportunity cost that depository institutions incur by not investing required reserves in interest-bearing assets. (Sic). The other component of IOR 
the federal funds target range and remained about 20 basis points above the discount rate on 3 -month Treasury bills $\left(i_{I O R}=i_{R F}+0.20 \%\right) .{ }^{37}$ This was a factor that increased banks' willingness to hold a large stock of excess reserves. Paying interest on excess reserves and supplying a large stock meant that the FOMC had switched from direct federal funds targeting to a floor system. ${ }^{38}$ Interest rates paid on other short-term financial securities (i. e., for example, commercial paper and Treasury bills), often move up or down roughly in parallel with the funds rate. Yields on long-term assets (i. e., corporate bonds and Treasury notes), are determined in part by expectations for the fed funds rate in the future. These enormous federal funds cannot be absorbed by banks because there is no sufficient demand for investments ${ }^{39}$ and for this reason, they cause only bubbles (Graph 10) in the financial market (are offered to financial investors using margin accounts ${ }^{40}$ and keep the deposit rate closed to zero. Then, this policy is not only inefficient, but bad (risky and unfair) for the economy.

is Interest on Excess Reserves (IOER), which is the interest paid on those balances ( $\mathrm{R}_{\mathrm{E}}$ ) that are above the level of reserves the depository institution is required to hold. [eq. (4)]. Paying IOER reduces the incentive for depository institutions to lend at rates much below IOER, providing the Federal Reserve additional control over the effective federal funds rate $\left(i_{F F}^{e f f}\right)$.

37 During the Zero Interest Rate Regime (2008:12-2015:11), on the average this $i_{I O R}$ was (Table A1):

$\bar{i}_{I O R}=\bar{i}_{R F}+0.20 \%=0.078 \%+0.20 \%=0.278 \%$. This rate is now $(8 / 1 / 2019): i_{I O R}=2.10 \%$. See, "Interest on Required Reserve Balances and Excess Balances",

https://www.federalreserve.gov/monetarypolicy/reqresbalances.htm . Then, if banks are receiving interest $(2.10 \%=1.90 \%+0.20 \%)$ from the Fed, why to pay interest on deposits? They do not need more funds from depositors as long as the Fed provides this enormous liquidity ( $\mathrm{R}_{\mathrm{E}}$ ). Banks kept a deposit rate closed to zero ( $\left.i_{D}=0.05 \%\right)$, which was giving a negative real deposit rate $\left(r_{D}=-1.536 \%\right)$. Now, $r_{D}=-1.921 \%$ (Table A1). This is another proof that the Fed has failed (or it has no interest) to maximize the depositors' interest income and consequently, their welfare. Fed is supplying these trillions of dollars reserves to banks and because there is no demand for investments, banks cannot offer loans, so they do not need all these excess reserves. Thus, the Fed offers to banks a high interest rate to avoid the opposition of the banks against this strange QE policy. (Sic). See, Kallianiotis (2019).

38 See, Bindseil (2016). Vice President and Economist Stephen Williamson explained that given the large stock of reserves outstanding, the Fed should, in principle, be able to target the federal funds rate (or the interest rate banks charge when they lend to each other overnight) by setting the interest rate on excess reserves (IOER). However, Williamson noted that the IOER was set at 0.25 percent from late 2008 through December 2015, while the fed funds rate has generally been 5 to 20 basis points lower than the IOER since early 2009. He wrote: "This difference between the IOER and the fed funds rate is typically ascribed to costs for commercial banks associated with borrowing on the fed funds market." Williamson noted that "the solution adopted by the Fed is unique in central banking-a floor system with a subfloor." The subfloor is dictated by the rate on what are called overnight reverse repurchase agreements, or ON-RRPs. See, "The Fed and Interest Rates: A Floor with a Subfloor". (Graph 11). https://www.stlouisfed.org/on-the-economy/2016/july/fed-interest-rates-floor-subfloor

39 The demand for investments depends on the demand for goods by the Americans and their demand depends on their income and employment, which depend on domestic production. With the outsourcing, this production has gone abroad and the income of Americans has fallen. The domestic aggregate demand can increase only if manufacturing and agriculture production will increase and jobs will come back to the country. Then, we need, here, a fiscal and a trade policy to improve these conditions that globalization has caused for many years. Monetary policy does not work by itself. The liberal central bank is in favor of liberals agenda, as the entire establishment, for the country: Russia $=>$ Racism $=>$ Recession $=>$ Revenge (against the country) $=>$ Restraint (globalization). The establishment allowed for 25 years (1994) an unfair trade with the emerging markets and the country (the entire western economies) is suffering. The fake news is exposing the lies in the tariff fight with China and affects negatively the financial market. (Fox News, August 23, 2019). The demand for bank loans has fallen. See, FRED, Commercial and Industrial Loans, All Commercial Banks.

https://fred.stlouisfed.org/series/CILACBQ158SBOG

40 See, The Latest Margin Data. https://www.advisorperspectives.com/dshort/updates/2019/08/20/margindebt-and-the-market-up-0-98-in-july 
In summary, the Fed started with a $\mathrm{QE}$ and began paying interest of 25 basis points on excess reserve balances in December 2008, increasing the rate to 50 basis points in December 2015. At first blush, this would seem to give the federal funds rate a floor, a rate below which it would not go. The expectation was that an institution that wished to lend in the federal funds market and earn interest could always hold its reserves with the Federal Reserve (effectively "lending" to the Fed) and earn IOER, which would remove the incentive to accept a rate lower than that in the federal funds market. However, the effective federal funds rate has been consistently lower than the IOER rate since its inception (Figure 3). The reason for this is that there are institutions, which have reserve accounts at the Fed and participate in the federal funds market, but they are not eligible for IOER. Primarily, these institutions are the government-sponsored enterprises (GSEs) ${ }^{41}$ Fannie Mae, Freddie Mac, and the FHLBs. These institutions are willing to accept a rate in the federal funds market that is lower than the IOER rate, and this drives the effective federal funds rate below the IOER rate.

\section{TESTING THE TRADITIONAL MONETARY POLICY RULES}

According to Taylor's (1993) original version of the rule, the nominal interest rate should respond to divergences of actual inflation rates from target inflation rates and of actual GDP from potential GDP:

$\bar{i}_{F F_{t}}=\pi_{t}+r_{t}^{*}+\alpha_{\pi}\left(\pi_{t}-\pi_{t}^{*}\right)+\alpha_{q}\left(q_{t}-\bar{q}_{t}\right)$

where, $\bar{i}_{F F_{t}}=$ the target short-term nominal interest rate (the federal funds rate), $\pi_{t}=$ the rate

of inflation as measured by the GDP deflator, $\pi_{t}^{*}=$ the desired rate of inflation, $r_{t}^{*}=$ the assumed equilibrium real interest rate, $q_{t}=$ the logarithm of real GDP, and $\bar{q}_{t}=$ the logarithm of potential output, as determined by a linear trend.

In this equation, both $\alpha_{\pi}$ and $\alpha_{q}$ should be positive, as a rough rule of thumb, Taylor's (1993) paper proposed setting $\alpha_{\pi}=\alpha_{q}=0.5$. That is, the rule "recommends" a relatively high interest rate (a "tight" monetary policy) when inflation is above its target or when output is above its full employment level, in order to reduce inflationary pressure. It recommends a relatively low interest rate ("easy" monetary policy) in the opposite situation, to stimulate output.

Taylor's rule can be modified by using unemployment $\left(u_{t}\right)$ instead of GDP:

$\bar{i}_{F F_{t}}=\pi_{t}+r_{t}^{*}+\alpha_{\pi}\left(\pi_{t}-\pi_{t}^{*}\right)-\alpha_{u}\left(u_{t}-u_{t}^{N}\right)$

If inflation rate is above target, the central bank raises the federal funds rate, which encourages financial institutions to increase interest rates on their loans and mortgages. But the higher loans rates discourage borrowing and spending and thereby easing the upward pressure on prices. If the unemployment rate is above the natural level $\left(u_{t}^{N}\right)$, the Fed reduces the federal funds rate to lower the cost of capital and might increase investment, which will affect positively output and employment.

41 See, "government-sponsored enterprise (GSE)": (1) Housing: The eleven Federal Home Loan Banks (FHLBanks) (1932); Federal National Mortgage Association (Fannie Mae) (1938); Federal Home Loan Mortgage Corporation (Freddie Mac) (1970); Financing Corporation (FICO) (1987). (2) Veteran: National Veteran Business Development Corporation (1999). (3) Farming: Federal Farm Credit Banks (FCBanks) (1916); Federal Agricultural Mortgage Corporation (Farmer Mac) (1987). (4) Education: SLM Corporation (Sallie Mae) (1972-1995). 
Financial market plays a major role in market oriented economies and its optimal growth has a positive effect on investors' and consumers' confidence. The opposite happens, if growth is artificially enormous (abnormal bubbles), Graph 10. We are using, here, an augmented Taylor's equation by putting an extra term, the growth of the financial market $\left(g_{D J I A_{t}}\right)$, as follows,

$\bar{i}_{F F_{t}}=\pi_{t}+r_{t}^{*}+\alpha_{\pi}\left(\pi_{t}-\pi_{t}^{*}\right)-\alpha_{u}\left(u_{t}-u_{t}^{N}\right)+\alpha_{D J I A}\left(g_{D J I A_{t}}-g_{D J I A_{t}}^{*}\right)$

where, $g_{D J I A_{t}}=$ the actual growth of the DJIA index, $g_{D J I A_{t}}^{*}=$ the optimal (the bubble prevention) growth of the DJIA $\left(g_{D J A_{t}}^{*} \leq 7 \% \cong i_{10 Y T B}+5 \%\right)$, and $\alpha_{\pi}=0.25, \alpha_{u}=-0.50,{ }^{42}$ $\alpha_{D J I A}=0.25$

In addition, the Phillips curve can be written as follows:

$\pi_{t}=\pi_{t}^{e}+\varphi\left(q_{t-1}-q_{t}^{N}\right)$

or

$$
\pi_{t}=\pi_{t}^{e}-\psi\left(u_{t-1}-u_{t}^{N}\right)
$$

and we want to test empirically this Phillips curve during the two last monetary policy regimes (ZIRR and NR).

Further, to test the effectiveness of the monetary policy during these two regimes, a VAR model is constructed. We use a vector autoregression (VAR) model for the interrelated objective variables of the monetary policy ( djia $_{t}, r g d p_{t}, i_{10 Y T B_{t}}, p_{t}$, and $\left.u_{t}\right)^{43}$ as endogenous dependent variables and as a function of the lagged values of all these endogenous variables in the system and the policy instruments $\left(i_{F F_{t}}^{e f f}, m b_{t}\right.$, and $\left.m_{t}\right)$ as independent exogenous variables. The mathematical representation is as follows:

$$
\begin{aligned}
& \text { djia }_{t}=\alpha_{11} \text { djia }_{t-j}+\beta_{11} r g d p_{t-j}+\gamma_{11} i_{10 Y T B_{t-j}}+\delta_{11} p_{t-j}+\zeta_{11} u_{t-j}+c_{o}+\theta_{11} i_{F F_{t}}^{e f f}+\kappa_{12} m b_{t}+\lambda_{13} m_{t}+\varepsilon_{1 t} \\
& r g d p_{t}=\alpha_{21} d j i a_{t-j}+\beta_{21} r g d p_{t-j}+\gamma_{21} i_{10 Y T B_{t-j}}+\delta_{21} p_{t-j}+\zeta_{21} u_{t-j}+c_{o}+\theta_{21} i_{F F_{t}}^{e f f}+\kappa_{22} m b_{t}+\lambda_{23} m_{t}+\varepsilon_{2 t} \\
& i_{10 Y T B_{t}}=\alpha_{31} d j i a_{t-j}+\beta_{31} r g d p_{t-j}+\gamma_{31} i_{10 Y T B_{t-j}}+\delta_{31} p_{t-j}+\zeta_{31} u_{t-j}+c_{o}+\theta_{31} i_{F F_{t}}^{\text {eff }}+\kappa_{32} m b_{t}+\lambda_{33} m_{t}+\varepsilon_{3 t} \\
& p_{t}=\alpha_{41} d j i a_{t-j}+\beta_{41} r g d p_{t-j}+\gamma_{41} i_{10 Y T B_{t-j}}+\delta_{41} p_{t-j}+\zeta_{41} u_{t-j}+c_{o}+\theta_{41} i_{F F_{t}}^{\text {eff }}+\kappa_{42} m b_{t}+\lambda_{43} m_{t}+\varepsilon_{4 t} \\
& u_{t}=\alpha_{51} d j i a_{t-j}+\beta_{51} r g d p_{t-j}+\gamma_{51} i_{10 Y T B_{t-j}}+\delta_{51} p_{t-j}+\zeta_{51} u_{t-j}+c_{o}+\theta_{51} i_{F F_{t}}^{e f f}+\kappa_{52} m b_{t}+\lambda_{53} m_{t}+\varepsilon_{5 t}
\end{aligned}
$$

where, djia $_{t}=$ LUSDJIA $=$ ln of U.S. Dow Jones Industrial Average Index, $r g d p_{t}=$ LUSRGDP2012 $=\ln$ of U.S. real GDP, $i_{10 Y B_{t}}=$ US10YTB $=$ U.S 10-Year Treasury Bonds Rate, $p_{t}=$ LUSCPI $=\ln$ of

42 The coefficient of unemployment are higher because full employment is the most important objective of every policy. Citizens of a country need work (employment), certainty (zero risk), confidence for the financial market (no bubbles and enormous declines), and low inflation (the true cost of production of a good).

${ }^{43}$ Which are: In of DJIA, In of RGDP, yield on 10YTB, ln of CPI, and USU rate. 
U.S. CPI, $\boldsymbol{u}_{t}=$ USU = U.S. unemployment rate, $i_{F F_{t}}^{e f f}=$ USFFR $=$ U.S. effective federal funds rate, $m b_{t}=$ LUSMB $=\ln$ of U.S. monetary base, and $m_{t}=$ LUSM2 = ln of U.S. money supply (M2).

Now, we use the Taylor's rule to see if the target federal funds rate was the appropriate according to the rule:

$\bar{i}_{F F_{t}}=\pi_{t}+r_{t}^{*}+\alpha_{\pi}\left(\pi_{t}-\pi_{t}^{*}\right)-\alpha_{u}\left(u_{t}-u_{t}^{N}\right)$

The coefficients are: $\alpha_{\pi}=0.5$ and $\alpha_{u}=-0.5$, the other variables are $r_{t}^{*}=1 \%, \pi_{t}^{*}=2 \%$, and $u_{t}^{N}=4 \%, \pi_{t}$, and $u_{t}$ are the averages of each period. The target federal funds rate was between $(0.00 \%-0.25 \%)$ for the period 2008:12 to 2015:11. ${ }^{44}$ Thus, by using data from Table $\mathrm{A} 1, i_{F F}$ must have been:

$i_{F F}=1.586 \%+1 \%+0.5(1.586 \%-2 \%)-0.5(7.838 \%-4 \%)=0.46 \%$; but, it was between $0 \%$ and $0.25 \%$ (average $\bar{i}_{F F}^{e f f}=0.129 \%$ ), which was low.

From 2015:12 to 2019:06 the $i_{F F}$ must have been:

$i_{F F}=1.971 \%+1 \%+0.5(1.971 \%-2 \%)-0.5(4.286 \%-4 \%)=2.8135 \%$; but it was between $0.25 \%$ and $2.50 \%$ (average $\bar{i}_{F F}^{e f f}=1.268 \%$ ), which was too low.

Thus, Taylor's rule recommends higher federal funds rate $\left(i_{F F} \cong 3 \%\right)$. This is also our view that the $i_{F F}>3 \%$ to reduce the financial market bubble and to make the real rate of interest positive and the deposit rate above the inflation rate $\left(i_{D}>\pi\right)$.

Then, by using the Bullard rule, ${ }^{45}$ we have:

$$
\bar{i}_{F F_{t}}=\rho i_{F F_{t-1}}+(1-\rho)\left[r_{t}^{*}+\pi^{*}+\phi_{\pi}\left(\pi_{t}-2 \%\right)+\phi_{q}\left(u_{t}-4 \%\right)\right]
$$

For the ZIRR (2008:12-2015:11) the $i_{F F}$ must have been:

$i_{F F}=0.85(0.25 \%)+0.15[1 \%+2 \%+1.5(1.586 \%-2 \%)+1(7.838 \%-4 \%)=1.14505 \%$; but it was $0.129 \%$, very low.

For the NR (2015:12-2019:06) the $i_{F F}$ must have been:

(i) When $\bar{i}_{F F}=0.50 \%$ : $i_{F F}=0.85(0.25 \%)+0.15[1 \%+2 \%+1.5(1.971 \%-2 \%)+1(4.286 \%-4 \%)=0.699 \%$, which was low.

(ii) When $\bar{i}_{F F}=2.50 \%$ :

$i_{F F}=0.85(2.25 \%)+0.15[1 \%+2 \%+1.5(1.906 \%-2 \%)+1(4.389 \%-4 \%)=2.3997 \%$, which was good, but a little high.

(iii) When $\bar{i}_{F F}=2.25 \%$ (today's target rate);

$i_{F F}=0.85(2.00 \%)+0.15[1 \%+2 \%+1.5(1.971 \%-2 \%)+1(4.286 \%-4 \%)=2.186 \%$, which is relatively good.

\footnotetext{
${ }^{44}$ For federal funds target rate, see, http://www.fedprimerate.com/fedfundsrate/federal funds rate history.htm 45 See, St. Louis Fed President, James Bullard (2018) rule.
} 
Even Bullard's rule, who is a policy maker, President of St. Louis Fed, shows that the target federal funds rate is relatively low.

We continue by applying the data to our eq. (7), which includes the growth of the financial market, we receive the following results:

$\left(\alpha^{\prime}\right)$ From $2008: 12$ to $2015: 11$ the $i_{F F}$ must have been:

$$
1.586 \%+1 \%+1 / 4(1.586 \%-2 \%)-1 / 2(7.838 \%-4 \%)+1 / 4(9.952 \%-7 \%)=1.3015 \%
$$

( $\left.\beta^{\prime}\right)$ From 2008:12 to 2019:06 the $i_{F F}$ must be:

$$
1.971 \%+1 \%+1 / 4(1.971 \%-2 \%)-1 / 2(4.286 \%-4 \%)+1 / 4(11.348 \%-7 \%)=3.908 \%
$$

Thus, the ZIRR and the NR are both having a very low federal funds rate (Table A1), $(0.129 \%<1.3019 \%)$ and $(1.268 \%<3.908 \%)$, compared to these rates calculated above. These low average federal funds rates do not satisfy the ultimate objective of monetary policy.

We also test the Phillips curve for the two Eras. Low inflation (Graph 9) together with high unemployment (Graph 8) supported the conventional wisdom that there is a Phillips curve, here; but, the data discredited the Phillips curve as a policy framework, which is questionable. The only explanation can be that the high unemployment reduces personal income and affects negatively the aggregate demand ( $A D \downarrow$ ), then prices are falling or something wrong with the official measurement of inflation and unemployment or inflation is not a demand-side any more, but a monetary phenomenon and a supply-side one.

By testing the Phillips curve equation, eq. (9), we found as results:

(1) 1950:04-2019:06 (the last 69 years)

$$
\begin{aligned}
\pi_{t}= & 1.031^{* * *} \pi_{t}^{e}-0.088\left(u_{t-1}-u_{t}^{N}\right) \\
\quad(0.036) & (0.063) \\
R^{2}= & 0.351, S E R=3.350, D-W=2.031, N=831
\end{aligned}
$$

(2) 2008:12-2015:11 (ZIRP Regime)

$$
\begin{aligned}
\pi_{t}= & 0.839^{* * * *} \pi_{t}^{e}+0.100\left(u_{t-1}-u_{t}^{N}\right) \\
\quad(0.291) & (0.141) \\
R^{2}= & 0.126, S E R=3.358, D-W=2.001, N=84
\end{aligned}
$$

(3) 2015:12-2019:06 (New Regime)

$$
\begin{aligned}
& \pi_{t}=0.984^{* * *} \pi_{t}^{e}-0.193\left(u_{t-1}-u_{t}^{N}\right) \\
& \quad(0.197) \quad(0.726) \\
& R^{2}=0.066, S E R=2.251, D-W=1.858, N=43
\end{aligned}
$$

The coefficient of unemployment $(\psi)$, for the entire period (1950:04-2019:06), is negative ( $\psi<0$ ), but statistically insignificant. During the ZIRP period (2008:12-2015:11) the unemployment coefficient became positive $(\psi>0)$, but insignificant. Currently with the New Regime (2015:12-2019:06) the sign of unemployment coefficient became again negative $(\psi<0$ 
), but it is insignificant. Thus, these results show that the Phillips curve does not hold any more and especially, during the ZIRP regime. ${ }^{46}$ (sic).

All the empirical results show that the federal funds rate was and still is very low for eleven years. The latest monetary policy has overturned all the economic theories. It introduces the "new" dread-theories of the $21^{\text {st }}$ century. Table A1 gives the average values and the standard deviations of different variables during the ZIRR and during the current New Regime (NR). We can see the low federal funds rate, the enormous liquidity (the immense money supply), ${ }^{47}$ the negative real rates of interest, the low economic growth, the high unemployment, ${ }^{48}$ and the low inflation (very strange and odd official data). ${ }^{49}$ The VAR results

46 See also, Williamson (2018) and Summers (2017). In fact, we have become consumers and we just borrow and consume even when prices are increasing. This system from "capitalism" is becoming "debtism". (Sic).

47 Graph 7: The U.S. Money Supply (M2):

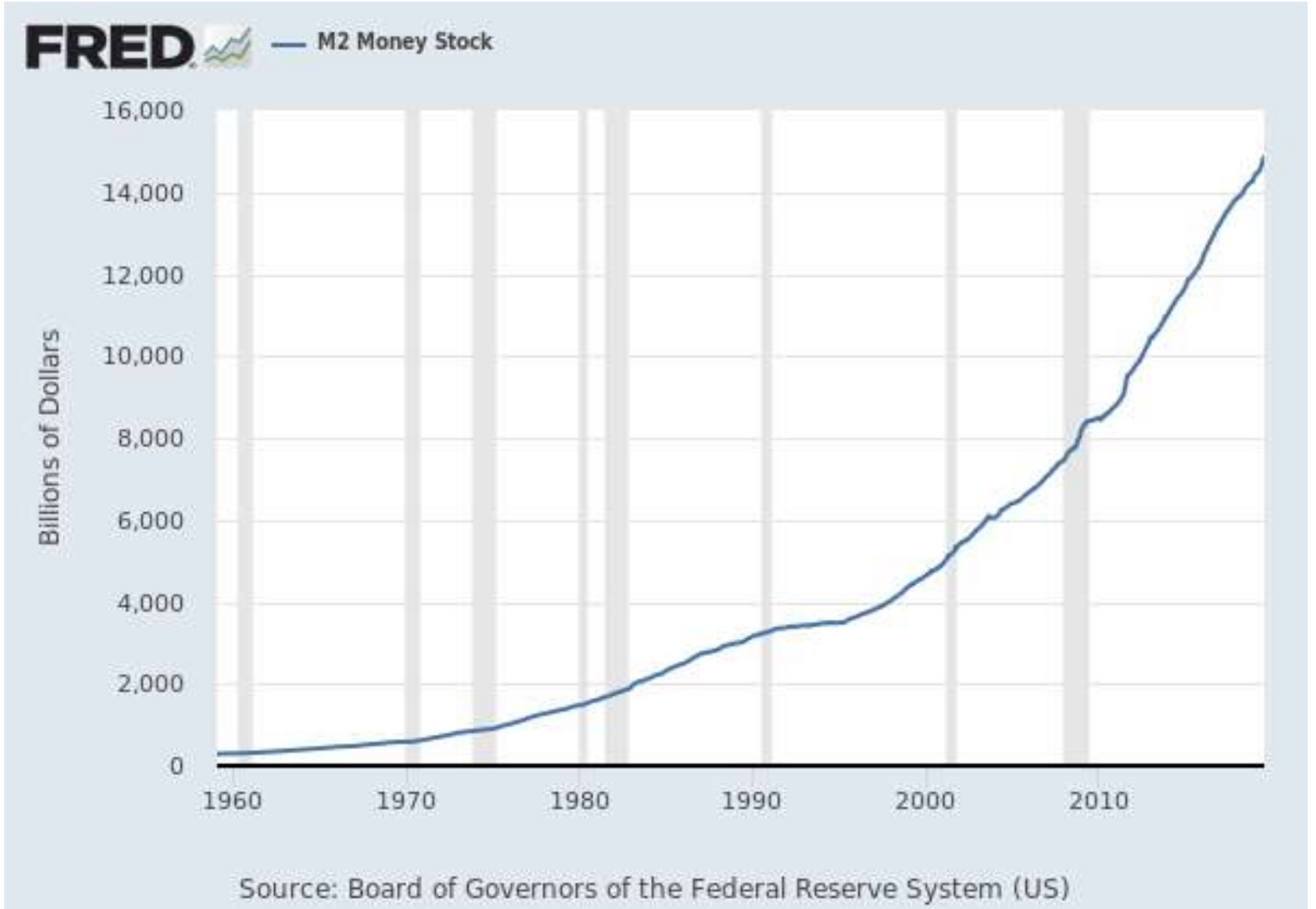

Source: https://fred.stlouisfed.org/series/M2/29/. Also, https://www.bing.com/images/search?view=detailV2\&id=9DFFEECC3FFB0D825DED843AF15F85CA107EBB4F \&thid=OIP.YH-

zy5ucv6KvZEADHuZi0wHaFK\&mediaurl=https\%3A\%2F\%2Ffred.stlouisfed.org\%2Ffredgraph.png\%3Fid\%3DM2 SL\%26nsh\%3D1\%26width\%3D600\%26height\%3D400\&exph=418\&expw=600\&q=fred+m2+money+supply\&sel ectedindex $=0 \& a j a x h i s t=0 \& v t=0 \&$ eim $=1,2,6$. Further, Source: https: $/ /$ tradingeconomics.com/unitedstates/money-supply-m2 . Furthermore, Source: Economagic.com

48 Unemployment Data Series. Last Updated: August 2nd, 2019. The ShadowStats Alternate Unemployment Rate for July 2019 is $21.0 \%$.

Graph 8: U.S. Unemployment Rate: 
of eq. (10) are given in Tables A2 and A3, which show that monetary policy (its instruments, $\mathrm{i}_{\mathrm{FF}}$ , $\mathrm{MB}$, and $\mathrm{M}^{\mathrm{s}}$ ) have no major significant effects on the ultimate objective variables ( $D J I A, G D P$, $i_{L-T}, P$, and $u$ ). During 2008:12-2015:11, the decrease of the federal funds rate has reduced unemployment, but the growth of monetary base has increased unemployment. Then, during the current NR, the increase in monetary base and money supply have a drastic significant effect on DJIA (an enormous bubble). ${ }^{50}$ Also, the increase in $i_{F F}$ and reduction of MB have

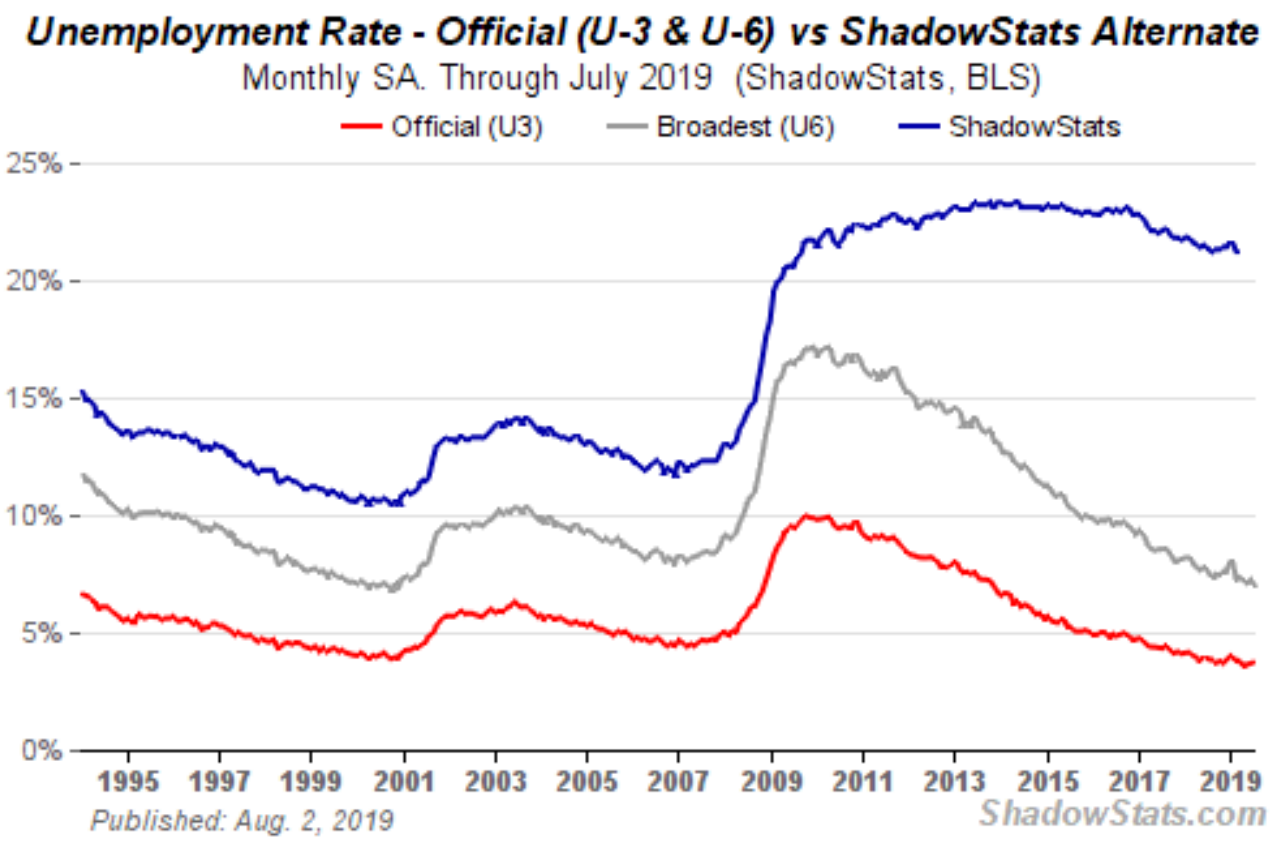

Source: http://www.shadowstats.com/alternate data/unemployment-charts

${ }^{49}$ Graph 9: Inflation Rate:

\section{Consumer Inflation - Official vs ShadowStats (1980-Based) Alternate}

Year to Year Change. Through July 2019. (BLS, SGS)
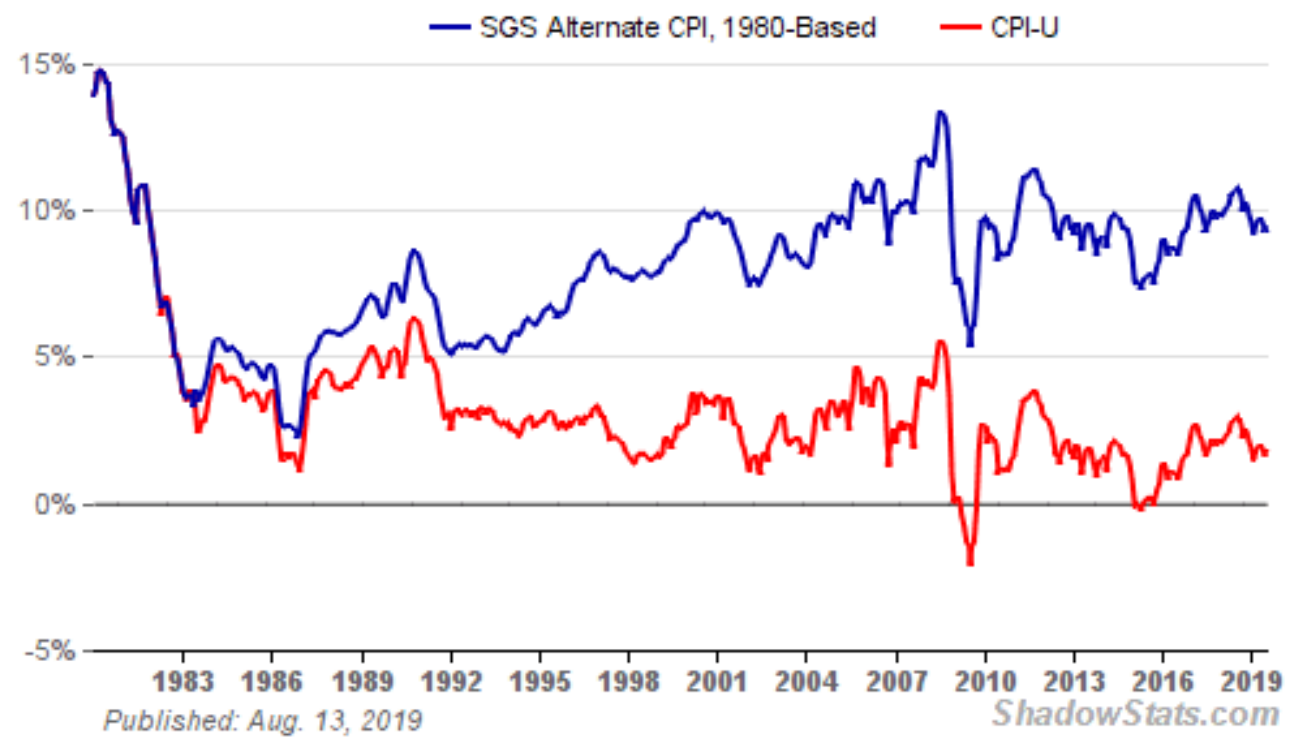

Source: http://www.shadowstats.com/alternate data/inflation-charts

50 The DJIA from 6,547.05 (March 9, 2009) reached 17,425.03 (December 2015), a 24.91\% p.a. growth during the ZIRR and became 27,359.16 (July 15, 2019), a 15.92\% p.a. during the NR. It is a total growth of 20,812.11 points or an average growth of $30.77 \%$ p.a. If this is not Fed's bubble, what else can it be?

Graph 10: Dow Jones Industrial Average Index: 
improved the growth of the GDP. The increase in money supply (M2) has a significant effect on prices (prices went up). No effects on long term interest rates and unemployment.

Lastly, testing correlation and causality between the monetary instruments, we have the following results:

(a) From 1950 to 2019:

$\rho_{i_{F F}, M 2}=-0.572$ (liquidity effect) and $M 2 \Rightarrow i_{F F}\left(F=2.446^{*}\right)$

$\rho_{i_{F F}, M B}=-0.582$ (liquidity effect) and no causality

$\rho_{M B, M 2}=+0.941$ and $M B \Rightarrow M 2\left(F=9.769^{* * *}\right)$

(b) From 2008 to 2019:

$\rho_{i_{F F}, M 2}=+0.287$ (no liquidity effect)

and $M 2 \Rightarrow i_{F F}\left(F=11.774^{* * *}\right), i_{F F} \Rightarrow M 2\left(F=3.483^{* *}\right)_{51}$

$\rho_{i_{F F}, M B}=-0.160$ (liquidity effect)

and $M B \Rightarrow i_{F F}\left(F=5.201^{* * *}\right), i_{F F} \Rightarrow M B\left(F=3.818^{* *}\right)$

$\rho_{M B, M 2}=+0.858$ and $M B \Rightarrow M 2\left(F=2.409^{*}\right)$

These results are in consent with all the others. So the latest monetary policy is incompatible and contradictory with the traditional monetary policies and economic theories.

USDJIA

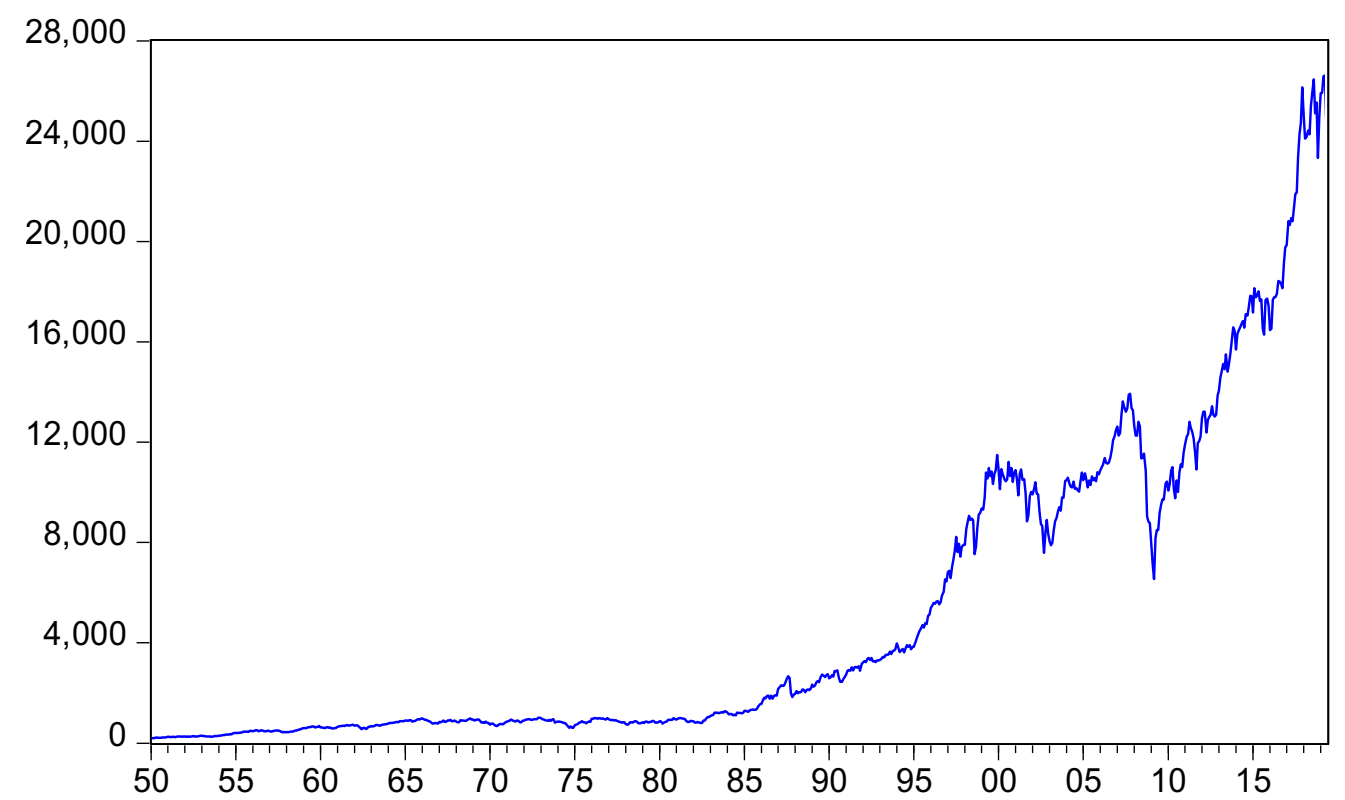

Source: Yahoo, Finance

51 This latest monetary policy has invalidated (inverted) the economic laws. (Sic). 


\section{POST CRISIS IMPLICATIONS OF MONETARY POLICY}

These changes altered the fed funds market in a number of astonishing ways, including the types of financial institutions that were trading, the rates at which they were borrowing and lending, and the new tools fabricated by the FOMC that could effectively influence these market rates. Because banks were overflowed with reserves, their desire to borrow effectively vanished, and bank-to-bank lending largely disappeared. (Graph 11). ${ }^{52}$ However, once the Fed started paying interest on reserves to some (but not all) financial institutions, a new lending opportunity emerged. To understand this opportunity better, consider a financial institution ineligible to receive interest on reserves at the Fed, such as an FHLB. ${ }^{53}$ At the end of the day, it likely holds some amount of cash, but the highest overnight interest rate it could receive (what economists call its "outside option") was a zero percent net return.

Hence, these changes to the fed funds market required policymakers to devise a new system for implementing monetary policy. Since the market rate was no longer primarily determined by banks' supply and demand for reserves, typical open market operations would have essentially no effect on market rates. ${ }^{54}$ Instead, when the FOMC decided to raise interest rates after a long period at zero, it did so by adjusting the outside options of the lenders and the borrowers in this market via administered rates. The Fed had been controlling the outside option of eligible banks via the IOR rate since October 2008. However, if the Fed adjusted this

52 Graph 11: Key Features of the Federal Funds Market:

\section{Key Features of the Fed Funds Market}

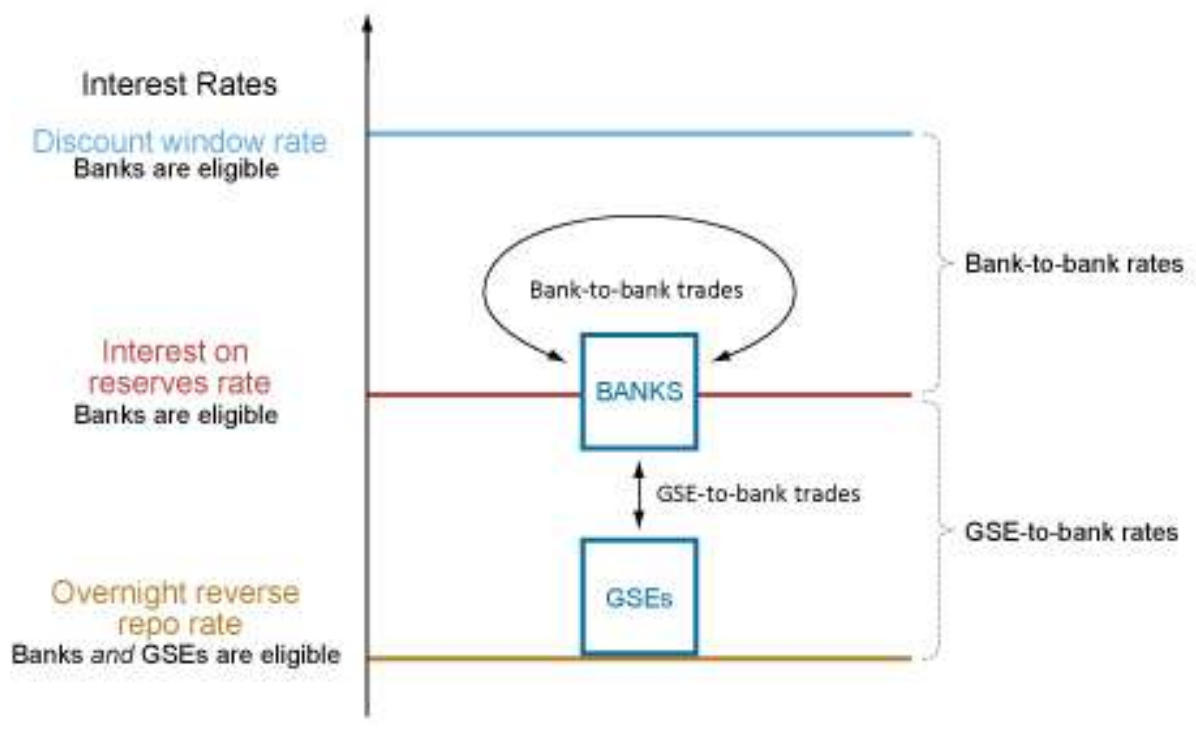

Source: Authors' conceptualization.

Note: As shown in the Graph, rates in the fed funds market are effectively split into two segments by the IOR rate. Government-sponsored enterprises (GSEs) lend to banks that then earn IOR on the additional funds. The agreed rates for these trades are typically between the ON RRP rate (the opportunity cost for the lender) and the IOR (the return for the borrower). Then, $i_{O N R R P}<i_{F F}^{e f f}<i_{I O R}<i_{D R}$. See, Afonso, Armenter, and Lester (2018),

https://libertystreeteconomics.newyorkfed.org/2018/07/size-is-not-all-distribution-of-bank-reserves-and-fedfunds-dynamics/comments/

53 The Federal Home Loan Banks provide funds to depository institutions in the form of loans collateralized by real estate. They were initially set up to provide liquidity to savings and loans but are now a source of funds for all banks.

54 If the Fed tried to conduct policy on pre-crisis terms, it would have had to execute very large open market operations to drain reserves in relatively short order. Selling large quantities of certain assets in a very short period would have negative side effects, as prices in these markets would likely experience sudden declines. 
rate alone, the gap between the two outside options would widen as the IOR increased and, as a result, market rates might not rise in sync with the IOR. So in September 2013 the FOMC introduced an instrument to adjust the outside option of ineligible institutions, too, via the overnight reverse repurchase agreement facility (ON RRP). ${ }^{55}$ In a reverse repurchase, the Desk sells a security to an eligible counterparty with an agreement to buy the security back at a specified date and price, with the interest rate computed from the difference between the original purchase price and the (higher) repurchase price. Importantly, the FOMC included a wide range of market participants as eligible counterparties at the ON RRP facility, including FHLBs and key money market funds. ${ }^{56}$ By adjusting the rate being offered at the ON RRP facility, the FOMC was thus adjusting the outside option of essentially all major financial institutions ineligible to earn IOR at the Fed.

Some of the difference in behavior between the foreign and domestic banks in their borrowing may be driven by the fact that the domestic banks are able to get funds from domestic deposits and from cash advances directly from the FHLBs. However, when we observe the total holdings of foreign-related institutions, we see their total asset growth has been driven mostly by their cash assets. Cash made up 5.34\% of foreign-related institutions' total assets at the beginning of 2007. By May 2016, it made up 43.77\%, (Figure 2). Foreign-related institutions have increased their holdings of cash by $\$ 0.80$ trillion since the end of the financial crisis. One explanation for this is that the domestic banks have moved out of the business of arbitraging the difference between the federal funds rate and the IOER rate. They currently fund less of their operations with wholesale cash relative to foreign banking organizations because the foreign banking organizations are taxed less from a capital or insurance requirement standpoint than domestic organizations.

\section{POLICY IMPLICATIONS: NORMALIZATION OF THE BALANCE SHEET}

In the summer of 2017 the FOMC announced its intention to stop reinvesting the proceeds from maturing assets (such as mortgage-backed securities) on its balance sheet. This decision marked the beginning of the Fed unwinding or "normalizing" its balance sheet. As the Fed's balance sheet shrinks, excess reserves in the banking sector decline. (Graph 1). However, at the time, the FOMC did not provide an explicit endpoint for this process. ${ }^{57}$

More recently, in January 2019 the FOMC announced how it planned to hold "no more securities than necessary to implement monetary policy efficiently and effectively": by using a "regime in which an ample supply of reserves ensures that control over the level of the federal funds rate and other short-term interest rates is exercised primarily through the setting of the Federal Reserve's administered rates, and in which active management of the supply of reserves is not required." 58 In other words, the FOMC decided to shrink the balance sheet until reaching the minimal size still consistent with "ample" excess reserves, and to use the ON RRP

\footnotetext{
55 Senyuz and Tase (2017), https://doi.org/10.17016/2380-7172.2069.

${ }^{56}$ For more information about eligible counterparties at the ON RRP facility, see, https://www.newyorkfed.org/markets/rrp_counterparties.

57 In its June 14, 2017, statement, the FOMC announced only that "the Federal Reserve's securities holdings will continue to decline in a gradual and predictable manner until the Committee judges that the Federal Reserve is holding no more securities than necessary to implement monetary policy efficiently and effectively." See, https://www.newyorkfed.org/medialibrary/media/markets/omo/SOMAPortfolioandIncomeProjections July201 7Update.pdf

${ }^{58}$ See, "Policy Normalization", https://www.federalreserve.gov/monetarypolicy/policy-normalization.htm . Also, "Why the Fed Pays Interest on Banks' Reserves", https://www.stlouisfed.org/open-vault/2018/april/why-fedpays-interest-banks-reserves . Further, "Why Is the Fed Paying So Much Interest to Banks?", https://www.truthdig.com/articles/why-is-the-fed-paying-so-much-interest-to-banks/.
} 
and IOR rates to achieve the target fed funds rate. The target federal funds rate was between $2.25 \%$ and $2.50 \% .{ }^{59}$ Currently, it is between $2.00 \%$ and $2.25 \% .60$

This decline in aggregate excess reserves ${ }^{61}$ changes the individual behavior of market participants, and this in turn affects overall market conditions in the fed funds market, including interest rates and trading volume. In particular, if total excess reserves decline enough, the market will transition from the ample-reserve ( $\dot{\pi} \alpha \rho \kappa \tilde{\eta} \delta\llcorner\alpha \theta \varepsilon \dot{\varepsilon} \sigma \mu \alpha)$ regime, in which open market operations have little effect, to the pre-crisis scarce-reserve ( $\alpha \nu \varepsilon \pi \alpha \rho \kappa \tilde{\eta}$ $\delta\llcorner\alpha \theta \varepsilon \dot{\varepsilon}(\mu \alpha)$ regime. However, it is difficult to forecast when this transition will occur because it depends not only on the level of excess reserves in the market, but also on the distribution of these reserves across banks, which is hard to predict.

The question is now: When are reserves no longer 'ample'? How much must total reserves shrink before we see these changes? Because the logic above suggests that the fed funds rate should move from one corridor to another when enough banks find themselves with scarce reserves, it is not sufficient to know the total level of reserves. In addition, we need to know the distribution of those reserves across banks! To see why, consider what would happen if the total amount of excess reserves declined by $\$ 100$ billion and the entirety of this decline came off the balance sheets of banks already close to their reserve requirements. This would immediately force a number of banks to enter the fed funds market as borrowers, prompting other banks to lend above the IOR, thus raising rates. However, if this decline in reserves came off the balance sheets of banks far from their reserve requirements, it would have little effect; all banks would continue to borrow from FHLBs at rates below the IOR.

Consequently, to forecast the level of reserves at which the market transitions from ample to scarce reserves, we need to predict the distribution of reserves across banks as the Fed's balance sheet shrinks. Several factors determine this distribution, including each bank's size and the regulatory costs they face. In a recent paper by Afonso, Armenter, and Lester (2018), they estimate the total quantity of reserves consistent with the fed funds rate returning to a corridor between the IOR and discount-window rates. Their benchmark model suggests an answer of approximately $\$ 900$ billion. However, they find that their estimates are quite sensitive to what they assume about the evolution of the distribution of reserves. In particular, assuming that the majority of the decline in aggregate reserves is absorbed by the smallest or largest banks, respectively, produces estimates as large as $\$ 1.1$ trillion and as small as $\$ 500$ billion.

Lately, that the Fed and the FDIC have unilaterally enacted policies that have decreased the role of domestic institutions and increased the role of foreign institutions in the federal funds market, the link between federal funds policy and the real economy is more complex. When a

\footnotetext{
${ }^{59}$ Federal Reserve officials held their benchmark interest rate steady on Wednesday June 9, 2019, but hinted they would cut rates in the months ahead if the economic outlook weakens. Nine of 10 members of the rate-setting committee voted to maintain the federal-funds rate in a range between $2.25 \%$ and $2.5 \%$. St. Louis Fed President James Bullard dissented in favor of lowering rates, [see his calculation in (ii), p. 18]. This was the first dissent since Fed Chairman Jerome Powell took lead of the central bank in February 2018. See, https://www.wsj.com/articles/fed-holds-rates-steady-hints-at-possible-cut-if-outlook-dims11560967516 ?tesla $=y \& \bmod =$ article inline

60 This new target rate started on July 31, 2019. See, https://www.bankrate.com/rates/interest-rates/federalfunds-rate.aspx . Also, "Federal Funds Data", https://apps.newyorkfed.org/markets/autorates/fed\%20funds 61 In July 2008 they were $\$ 1.912$ billion; they reached their maximum in August 2014 of $\$ 2,699.966$ billion and lately (June 6,2019 ) they became $\$ 1,376.568$ billion. Now (July 2019), they started going up to $\$ 1,378.447$ billion. See Graph 6.
} 
target rate increase is announced; is it accompanied by an increase in the IOER rate? Is the increase accomplished by a sale of securities that are held by the Fed, or is it accomplished by even less straightforward means, such as the Fed's participation in the repo market? This complexity of monetary policy is making its effectiveness reprehensible.

As it was mentioned above and it is known to every saver, the $i_{D} \cong 0 \%$ since 2008 . "Now, however, the average savings account pays only $0.10 \%$ annually-that's one-tenth of $1 \%$-and many of the country's biggest banks pay less than that. If you were to put $\$ 5,000$ in a regular Bank of America savings account (paying 0.01\%) today, in a year you would have collected only 50 cents in interest. That's true for most of us, but banks themselves are earning $2.4 \%$ on their deposits at the Federal Reserve. These deposits, called 'excess reserves', include the reserves the banks got from our deposits, and on which they are paying almost nothing; and unlike with our deposits, there is no $\$ 250,000$ cap on the sums banks can stash at the Fed amassing interest. A whopping \$1.5 trillion in reserves are now sitting in Fed reserve accounts. (Graph 6). The Fed rebates its profits to the government after deducting its costs, and interest paid to banks is one of those costs. That means we, the taxpayers, are paying $\$ 36$ billion annually to private banks for the privilege of parking their excess reserves at one of the most secure banks in the world-parking them, rather than lending them out." 62 This policy tool is, if not anything else, a criminal policy against small savers (investors) and poor taxpayers. Political leaders have to do something for these corrupted and controlled by the "economic elite" private central banks. Their policies are ineffective for the economy and anti-social for the people.

Each of these decisions (Fed's policies) affects market institutions and their constituent participants differently. Under some regimes, foreign banks may be affected more than small commercial domestic banks and so forth. Until the various possible effects can be sorted out, we might expect the Fed to behave in a way that is as neutral as possible in the sense of not inducing massive institutional shifts. Making interest rate increases neutral while still changing the rate at which banks lend to each other is harder now. Because the current balance sheet is so huge $(\$ 3,761.508$ billion with September 4,2019$),{ }^{63}$ an announced policy rate increase could possibly generate surprising results. The margin requirements are very low $\left(r_{m}=50 \%\right)$, which contribute to the financial market bubbles and to the risk of banks. The margin requirements must be $r_{m}=100 \%$.

The level of banks' capital is another factor that must be considered by the regulators (central bank, FDIC, comptroller of the currency, etc.). A low capital level is increasing the cost of financial crises and the bank capital affects the real economy. Risk-averse consumers prefer higher capital levels because it increases the financial stability in the economy and the world. The tax-payers cannot bailout the corrupted and risk-seeking financial institutions in case of a crisis, as it happened in 2008 because it is completely unethical. Firestone, Lorenc, and Ranish (2019) by evaluating the economic costs and benefits of bank capital in the U.S., they found that the optimal capital ratio is from just over $13 \%$ to $26 \%{ }^{64}$ The current average capital ratio is $12.5 \%$ for the U.S. banks.

62 See, Ellen Brown, "Why Is the Fed Paying So Much Interest to Banks?", https://www.truthdig.com/articles/why-isthe-fed-paying-so-much-interest-to-banks/. See also, "2.4\%, Why Is the Fed Paying So Much Higher Interest Rate to Banks?", https://www.econmatters.com/2019/04/24-why-is-fed-paying-so-much-higher.html

63 See Graph 1, https://fred.stlouisfed.org/series/WALCL

64 See, Firestone, Lorenc, and Ranish (2019). 
Emphatically, the former heads of the Federal Reserve made their case Monday (August 5, 2019) for the central bank to remain independent and free from short-term political pressures, ${ }^{65}$ an implicit rebuttal to President Trump's repeated criticism of this private institution. All four former still-living Fed chairs-Paul Volcker, Alan Greenspan, Ben Bernanke and Janet Yellen-cosigned an op-ed in The Wall Street Journal on Monday underlining their belief that the central bank and its leader should be allowed to serve without political pressures or "the threat of removal or demotion... for political reasons." "It is critical to preserve the Federal Reserve's ability to make decisions based on the best interests of the nation, not the interests of a small group of politicians," the former central bankers wrote. ${ }^{66}$ This rhetoric is very good, but what we see so far, it is that Fed's policies are made only for the

https://files.stlouisfed.org/files/htdocs/publications/review/2019/07/12/an-empirical-economic-assessmentof-the-costs-and-benefits-of-bank-capital-in-the-united-states.pdf.

65 But, President Woodrow Wilson had said that the U.S. lost control of its financial system by allowing its Central Bank to be independent of the government (private): "I am a most unhappy man. I have unwittingly ruined my country. A great industrial nation is controlled by its system of credit. Our system of credit is concentrated. The growth of the nation, therefore, and all our activities are in the hands of a few men. We have come to be one of the worst ruled, one of the most completely controlled and dominated Governments in the civilized world -- no longer a Government by free opinion, no longer a Government by conviction and the vote of the majority, but a Government by the opinion and duress of a small group of dominant men." [Woodrow Wilson President of the United States (1913-1921)]. Today, the Central Banks around the world are controlled by the "system of credit". (Sic). The governors in many central banks around the world are coming from MIT and were students of Stanley Fischer. (1) Stanley Fischer (ex-governor Bank of Israel), (2) Ben S. Bernanke (ex-governor U.S. Fed), (3) Mario Draghi (governor ECB), (4) Mervyn King (governor Bank of England), (5) Lucas Papademos (ex-governor of Bank of Greece, ex-ECB vice president, and ex-prime minister of Greece), (6) Athanassios Orphanides (ex-governor Bank of Cyprus), (7) Duwuri Subbarao (governor Reserve Bank of India), (8) Jose De Gregorio (Central Bank of Chile), (9) Charles Bean (King's deputy in Bank of England), and (10) Oliver Blanchard (IMF). Then, central bankers are all from MIT:

http://www.bloomberg.com/news/2012-01-12/rescuing-europe-from-debt-crisis-begins-with-men-of-mit-asmatter-of-trust.html. Stanley Fischer was from January 1988 to August 1990 Vice President, Development Economics and Chief Economist at the World Bank. He then became the First Deputy Managing Director of the International Monetary Fund (IMF), from September 1994 until the end of August 2001. By the end of 2001, Fischer had joined the influential Washington-based financial advisory body, the Group of Thirty. After leaving the IMF, he served as Vice Chairman of Citigroup, President of Citigroup International, and Head of the Public Sector Client Group. Fischer worked at Citigroup from February, 2002 to April, 2005. He became Governor of the Bank of Israel on May 1, 2005, replacing David Klein, who ended his term on January 16, 2005. Fischer became an Israeli citizen, the aforementioned action being a prerequisite to this appointment. He has been involved in the past with the Bank of Israel, having served as an American government adviser to Israel's economic stabilization program in 1985. On May 2, 2010, Fischer was sworn in for a second term. Under his management, in 2010, The Bank of Israel was ranked first among central banks for its efficient functioning, according to IMD's World Competitiveness Yearbook. See,

http://www.bloomberg.com/news/2012-01-12/rescuing-europe-from-debt-crisis-begins-with-men-of-mit-asmatter-of-trust.html. Then, on January 10, 2014, United States President Barack Hussein Obama nominated Fischer to be Vice-Chairman of the U.S. Federal Reserve Board of Governors. On September 6, 2017, Stanley Fischer announced that he was resigning as Vice-Chairman for personal reasons effective October $13,2017$.

66 Paul Volcker, Alan Greenspan, Ben Bernanke and Janet Yellen say Fed should be free from short-term political pressures. See, "Former Fed Leaders Plea for Central Bank's Political Independence".

https://www.wsj.com/articles/former-fed-leaders-plea-for-central-banks-political-independence-11565051192 . Unfortunately, "Our money is not our money. We rent it. We have rented it since 1781 when the Bank of North America gained control of the money supply in the closing days of the Revolutionary War. We need to own our money as citizens responsible for both the government and the economy of the United States." See, Bob Blain, The Root of United States Public and Private Debt, 2017. Also, "Permit me to issue and control the money supply of a nation and I care not who makes its laws." (Mayer Amschel Rothschild, 1744-1812). Further, "The privilege of creating and issuing money is not only the supreme prerogative of Government, but it is the Government's greatest creative opportunity." (Abraham Lincoln, 1862). In addition, "Until the control of the issue of currency and credit is restored to government and recognized as its most conspicuous and sacred responsibility, all talks of the sovereignty of Parliament and of democracy is idle and futile." (William Lyon Mackenzie King, Canadian Prime Minister, 1874-1950). 
speculative financial market and its participants. Their effects on the real economy are insignificant and many times negative by creating bubbles and accomplishing the next recession. If the central bank's decisions were based on the best interest of the nation, it would have a policy to prevent recessions and not to cure them, after their creation. Federal Reserve Chairman Jerome Powell gave his most forceful warning yet (on August 23, 2019) about the risks to the U.S. economy from escalating trade tensions and the limits to the central bank's ability to cushion any fallout. He signaled that the central bank would follow its rate cut last month (July 31 2019). ${ }^{67}$

\section{CONCLUSION: FED'S POLICY DEDUCTIONS}

In response to the financial crisis, the Federal Reserve ${ }^{68}$ experimented with new tools (quantitative easing) and introduced new facilities, new programs and policies to stabilize markets, restore liquidity, and spur economic activity in a conflicting heterogeneous ${ }^{69}$ and forcefully interdependence world, which is very difficult and makes the monetary policy questionable. However, a byproduct of these changes was that the fed funds market was dramatically altered, necessitating a new framework for monetary policy implementation. More recently, as the Fed began to unwind some of these programs, it was forced to reassess the long-run size of its balance sheet (and the tools it intended to use for monetary policy implementation) given the current economic and regulatory environment. It has chosen to maintain a balance sheet that is unquestionably too large for the support of a market with necessary reserves, and there was no reason to use the social unfair administered (IOR and ON RRP) rates to achieve the target range. This "innovative" policy has negative effects (real deposit rate is negative for more than ten years) on interest rate on deposits, on tax payers wealth by subsidizing the interest on reserves, and on the financial market with the creation of bubbles. A lingering challenge is identifying the minimum balance sheet size consistent with these goals, as this requires forecasting the evolution of the distribution of reserves across banks. Actually, there was no need for these exaggerations.

Thus, the ZIRR and the NR (Table A1) are both having very low federal funds rates $(0.129 \%<1.3019 \%)$ and $(1.268 \%<3.908 \%)$ compared to these rates calculated above, eq. (7) and the other models, which do not satisfy the ultimate objective of monetary policy. Their biggest problem is the negative real rate of interest, their closed to zero deposit rates, which has a negative effect on savings, and the enormous bubble in the financial market. These monetary policies from 2008 up to now are unfair (redistribution of wealth), risky (creation of bubbles), ineffective (low growth and high unemployment), and suspicious (creeping inflation, etc.). Lately, this monetary policy has even inverted the yield curve. ${ }^{70}$

The empirical results show that the federal funds rate was and still is very low for eleven years. The latest monetary policy has overturned all the economic theories. It introduces the "new" dread-theories of the $21^{\text {st }}$ century. Table A1 gives the average values and the standard

\footnotetext{
${ }^{67} \mathrm{See}, \mathrm{https}$ ///www.wsj.com/articles/powell-says-fed-prepared-to-provide-stimulus-if-a-slowdown-hits-u-seconomy-11566568965

68 Investors believe central banks - the last bastion of the technocratic, globalized elite-can use their limited ammunition to stave off recession. Yet central banks may be dragged into the competitive fray. See, "As Global Order Crumbles, Risks of Recession Grow", https://www.wsj.com/articles/as-global-order-crumbles-risks-ofrecession-grow-11565784000

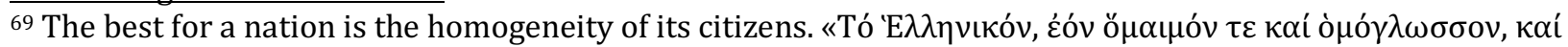

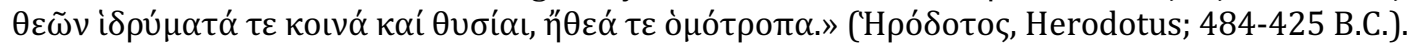

70 The 3-month T-Bills rate exceeds the 10 -year Treasury bonds rate: $i_{3 M T-\text { Bill }}=1.900 \%>i_{10 Y T B}=1.577 \%$. See, The Wall Street Journal, August 22, 2019, pp. A1 and B9.
} 
deviations of different variables during the ZIRR and during the current New Regime (NR). We can see the low federal funds rate, the enormous liquidity (the immense money supply), ${ }^{71}$ the negative real rates of interest, the unethical burden on taxpayers, the low economic growth, the high true unemployment, ${ }^{72}$ and the low official inflation (very strange and odd)..$^{73}$ The VAR results of eq. (10) are given in the Appendix, Tables A2 and A3, which show that monetary policy (its instruments, $\mathrm{i}_{\mathrm{FF}}, \mathrm{MB}$, and $\mathrm{M}^{\mathrm{s}}$ ) have no major significant effects on the ultimate objective variables (DJIA, GDP, $\mathrm{i}_{\mathrm{LT}}, \mathrm{P}$, and u). During 2008:12-2015:11, the decrease of the federal funds rate has reduced unemployment, but the growth of monetary base has increased unemployment. Then, during the current NR (2015:12-present), the increase in monetary base and money supply have a drastic significant effect on DJIA (an enormous bubble). ${ }^{74}$ Also, the increase in $\mathrm{i}_{\mathrm{FF}}$ and reduction of MB have improved the growth of the GDP. The increase in money supply (M2) has a significant effect on prices (prices went up). ${ }^{75}$ There are no effects on long term interest rates and unemployment. Then, monetary policy is ineffective.

This monetary policy is responsible for the bubbles in the financial markets and their volatility. Also, this unique public policy can create recessions very easily at any point in time. The recessions are coming from monetary policies and from the speculative financial market, which destroy consumers' and investors' confidence and lead the economy to recession. The fiscal policy can have drastic effects on the economy, especially, in the long-run. In our economy, fiscal policy is not very effective, too, because the other party (the Democrats, now) ${ }^{76}$ do not allow the administration to pursue an expansionary fiscal policy, which will improve aggregate demand (AD) and could help the growth and employment for the country; they want the current President to fail, so they can win next elections. This is the "democracy" of the current century; actually, does not exist.

Lastly, it seems that it is too late to do something to correct this destructive socio-economicopolitical system, which has a life of 379 years (since the British Revolution). Except, if the citizens (voters) of the world nations will wake up, as it happened in the U.S. with the 2016

\footnotetext{
71 See, M2. https://fred.stlouisfed.org/series/M2/29/. Also, https://www.bing.com/images/search?view=detailV2\&id=9DFFEECC3FFB0D825DED843AF15F85CA107EBB4F \&thid=OIP.YH-

zy5ucv6KvZEADHuZi0wHaFK\&mediaurl=https\%3A\%2F\%2Ffred.stlouisfed.org\%2Ffredgraph.png\%3Fid\%3DM2 SL\%26nsh\%3D1\%26width\%3D600\%26height\%3D400\&exph=418\&expw=600\&q=fred+m2+money+supply\&sel ectedindex=0\&ajaxhist=0\&vt=0\&eim=1,2,6. Further, https://tradingeconomics.com/united-states $/$ moneysupply-m2 Furthermore, Economagic.com

72 See, Unemployment Data Series. Last Updated: August 2nd, 2019. The ShadowStats Alternate Unemployment Rate for July 2019 was $21.0 \%$. See, U.S. Unemployment rate, http://www.shadowstats.com/alternate data/unemployment-charts

73 But the data show: $\rho_{M 2, C P I}=+0.980 ; C P I \Rightarrow M 2\left(F=7.153^{* * *}\right)$. The official inflation rate with July 2019 was 1.8\% and the SGS inflation (1980-Based) was 9\%. See, http://www.shadowstats.com/alternate data/inflationcharts

74 The DJIA from 6,547.05 (March 9, 2009) reached 17,425.03 (December 2015), a 24.91\% p.a. growth during the ZIRR and became 27,359.16 (July 15, 2019), a 15.92\% p.a. during the NR. A total growth of 20,812.11 points or an average growth of $30.77 \%$ p.a. See, Yahoo, Finance

75 This can be seen from the correlation and the causality of the ln of these two variables ( $\mathrm{m} 2$ and p):

$\rho_{m 2, c p i}=+0.982 ; c p i \Rightarrow m 2\left(F=8.547^{* * *}\right)$.

76 Bernie Sanders a top contender for the Democratic Party's 2020 presidential nomination, said Wednesday (9/4/2019) that he would support U.S. taxpayer-funded programs in developing countries that administer abortion as well as help give women access to birth control. He wants to use abortion to control population growth. These liberals are going back to the Malthusian theory. (Sic). Fox News, 9/5/2019.

https://www.foxnews.com/politics/bernie-sanders-climate-change-abortion-birth-control-julian-castro-aocfamily-cycle
} 
elections, in U.K. with the British referendum to leave EU (Brexit) in 2016, and in Europe with the 2019 European Parliament elections. This awaking has to be constant and growing among the young people because risks exceeds benefits of our uncontrolled system. But who will teach them, what is the best system for their future? Can the Ivy League Universities? ${ }^{77}$ Unfortunately, their objective is exactly the opposite.

\section{References}

Afonso, Gara, Roc Armenter, and Benjamin R. Lester (2018), “A Model of the Federal Funds Market: Yesterday, Today, and Tomorrow," Federal Reserve Bank of Philadelphia Working Paper 18-10 (2018). https://dx.doi.org/10.2139/ssrn.3131158. https://www.newyorkfed.org/research/staff reports/sr840.html

Afonso, Gara, Alex Entz, and Eric LeSueur (2013), “Who's Lending in the Fed Funds Market?” Federal Reserve Bank of New York Liberty Street Economics Blog, December 2nd.

Afonso, Gara, and Ricardo Lagos (2015), “Trade Dynamics in the Market for Federal Funds,” Econometrica, 83:1, January, pp. 263-313.

Amadeo, Kimberly (2019), "Fed Funds and How the Funds Market Works: The Secret to How The Fed Controls Interest Rates", May 21. https://www.thebalance.com/what-are-federal-reserve-funds-how-the-funds-marketworks-3305841

Armenter, Roc, and Benjamin Lester (2017), "Excess Reserves and Monetary Policy Implementation", Review of Economic Dynamics, 23, pp. 212-235. https://doi.org/10.1016/i.red.2016.11.002. https://www.sciencedirect.com/science/article/pii/S1094202516300448?via\%3Dihub

Banegas, Ayelen, and Manjola Tase (2016), "Reserve Balances, the Federal Funds Market and Arbitrage in the New Regulatory Framework", Board of Governors of the Federal Reserve System Finance and Economics Discussion Series 2016-079, September. https://papers.ssrn.com/sol3/papers.cfm?abstract id=3055299

Bindseil, Ulrich (2016), "Evaluating Monetary Policy Operational Frameworks," in Designing Resilient Monetary Policy Frameworks for the Future. Proceedings of the Federal Reserve Bank of Kansas City Jackson Hole Economic Policy Conference, Jackson Hole, WY, August 25-27, pp. 179-277.

https://www.kansascityfed.org/publications/research/escp/symposiums/ /media/6c10f54077ef4f70ae9214d 2ac5dad35.ashx

Bullard, James (2018), “Modernizing Monetary Policy Rules”, Federal Reserve bank of St. Louis, pp. 1-33. https://www.stlouisfed.org/ /media/files/pdfs/bullard/remarks/2018/bullard memphis economic club 18 oc tober_2018.pdf?la=en

Craig, Ben R. and Sara Millington (2017), "The Federal Funds Market since the Financial Crisis”, Federal Reserve Bank of Cleveland. https://www.clevelandfed.org/en/newsroom-and-events/publications/economiccommentary/2017-economic-commentaries/ec-201707-the-federal-funds-market-since-the-financial-crisis.aspx

Ennis, Huberto M., and John A. Weinberg (2013), "Over-the-Counter Loans, Adverse Selection, and Stigma in the Interbank Market.” Review of Economic Dynamics 16:4, pp. 601-616. https://doi.org/10.1016/j.red.2012.09.005.

Famiglietti, Matthew and Carlos Garriga (2019), "Predicting the Yield Curve Inversions that Predict Recessions: Part 1", Economic Synopses, N. 9, Federal Reserve Bank of St. Louis,

https://files.stlouisfed.org/files/htdocs/publications/economic-synopses/2019/04/12/predicting-the-yieldcurve-inversions-that-predict-recessions-part-1.pdf

Firestone, Simon, Amy Lorenc, and Ben Ranish (2019), “An Empirical Economic Assessment of the Costs and Benefits of Bank Capital in the United States”, Federal Reserve Bank of St. Louis, REVIEW, pp. 203-230. https://files.stlouisfed.org/files/htdocs/publications/review/2019/07/12/an-empirical-economic-assessmentof-the-costs-and-benefits-of-bank-capital-in-the-united-states.pdf

Hadjimichalakis, Michael G. (1982), Monetary Policy and Modern Money Markets, Lexington, Massachusetts: D.C. Heath and Company.

Kallianiotis, I.N. (2019), "Monetary Policy: Is the Dual Mandate of the Fed Maximizing the Social Welfare?”, International Journal of Economics and Financial Research, Vol. 5, No. 6, June, pp. 112-142.

https://arpgweb.com/journal/5/archive/06-2019/6/5,

77 See, https://www.universityreview.org/list-ivy-league-schools/ 
https://arpgweb.com/pdf-files/ijefr5(6)112-142.pdf

Kallianiotis, John N. (2018), The European Union and its Debt Crises: The Deception of the Greeks, Hauppauge, N.Y.: Nova Science Publishers, August 2018, ISBN: 978-1-53614-067-5. https://novapublishers.com/shop/theeuropean-union-and-its-debt-crises-the-deception-of-the-greeks/

Kallianiotis, John N. (2017), "Central Banks, Monetary Policy, and their Efficiency", (Chapter 1) in Monetary Policy: Perspectives, Strategies and Challenges, Harriet Ward (editor), New York: Nova Science Publishers.

Lester, Benjamin (2019), "Implementing Monetary Policy in a Changing Federal Funds Market”, Economic Insights, Federal Reserve Bank of Philadelphia, Vol. 4, Issue 2, Second Quarter, pp. 15-20.

McCauley, Robert, and Patrick McGuire (2014), “Non-U.S. Banks' Claims on the Federal Reserve," BIS Quarterly Review, March, pp. 89-97. https://ssrn.com/abstract=2457110.

Occhino, Filippo (2018), "Are the New Basel III Capital Buffers Countercyclical? Exploring the Option of a RuleBased Countercyclical Buffer", Federal Reserve Bank of Cleveland, https://www.clevelandfed.org/newsroom-andevents/publications/economic-commentary/2018-economic-commentaries/ec-201803-countercyclical-capitalbuffers.aspx

Potter, Simon (2017), "Implementing Monetary Policy with the Balance Sheet." Speech at the ECB workshop Money Markets, Monetary Policy Implementation, and Central Bank Balance Sheets, Frankfurt Am Main, Germany, November 6. https://www.bis.org/review/r171106f.pdf

Selgin, George (2017), "The Strange Official Economics of Interest on Excess Reserves", Alt-M, October 3. https://www.alt-m.org/2017/10/03/strange-official-economics-of-interest-on-excess-reserves/

Senyuz, Zeynep, and Manjola Tase (2017), “Overnight Reverse Repurchase (ON RRP) Operations and Uncertainty in the Repo Market", FEDS Notes, Washington: Board of Governors of the Federal Reserve System, October 19, https://doi.org/10.17016/2380-7172.2069.

Stella, Peter (2015), "Exiting Well”, Paper presented at the Joint Central Bank Conference Sponsored by the Swiss National Bank, the Bank of Canada, the Federal Reserve Bank of Atlanta, and the Federal Reserve Bank of Cleveland.

Summers, Lawrence H. (2017), "Less is More When It Comes to Federal Reserve Policy." Financial Times, May 7. https://www.ft.com/content/ab77d236-318c-11e7-9555-23ef563ecf9a

Taylor, John B. (1993), "Discretion versus Policy Rules in Practice”, Carnegie-Rochester Conference Series on Public Policy, 39, pp. 195-214. "Discretion versus Policy Rules in Practice" (PDF).

Williamson, Stephen D. (2019), "Interest on reserves, interbank lending, and monetary policy", Journal of Monetary Economics, Vol. 101, January, pp. 14-30.

https://www.sciencedirect.com/science/article/pii/S0304393218303805

Williamson, Stephen (2018), "Inflation Control: Do Central Bankers Have it Right?", Review, Federal Reserve Bank of St. Louis, Vol. 100, No. 2, Second Quarter, pp. 127-150.

https://research.stlouisfed.org/publications/review/2018/04/16/inflation-control-do-central-bankers-have-itright/

Yu, Edison (2016), “Did Quantitative Easing Work?” Federal Reserve Bank of Philadelphia Economic Insights, First Quarter, pp. 5-13. https://www.philadelphiafed.org/-/media/research-and-data/publications/economicinsights/2016/q1/eiq116 did-quantitative_easing_work.pdf?la=en. 


\section{APPENDIX}

Table A1

U.S. Average Values and Standard Deviations

\begin{tabular}{|c|c|c|c|c|}
\hline Zero Interest & Rate Regim & $008: 12-2015: 11)$ & New Regime (20 & 12-2019:06) \\
\hline & $\bar{R}$ & $\sigma_{R}$ & $\bar{R}$ & $\sigma_{R}$ \\
\hline USFFR & $0.129 \%$ & $0.040 \%$ & $1.268 \%$ & $0.768 \%$ \\
\hline USRFFR & $-1.458 \%$ & $3.570 \%$ & $-0.703 \%$ & $2.376 \%$ \\
\hline USMB & 2866.094 & 833.296 & 3688.220 & 207.875 \\
\hline LUSMB & 7.918 & 0.298 & 8.211 & 0.058 \\
\hline GUSMB & $14.289 \%$ & $37.538 \%$ & $-5.445 \%$ & $22.280 \%$ \\
\hline M2 & 9987.648 & 1301.828 & 13621.86 & 669.194 \\
\hline LUSM2 & 9.201 & 0.130 & 9.518 & 0.049 \\
\hline GUSM2 & $6.163 \%$ & $6.395 \%$ & $5.187 \%$ & $3.852 \%$ \\
\hline USCPI & 227.366 & 8.464 & 246.693 & 5.685 \\
\hline LUSCPI & 5.426 & 0.038 & 5.508 & 0.023 \\
\hline USINF & $1.586 \%$ & $3.571 \%$ & $1.971 \%$ & $2.295 \%$ \\
\hline US10YTB & $2.586 \%$ & $0.628 \%$ & $2.369 \%$ & $0.446 \%$ \\
\hline USR10YTB & $1.000 \%$ & $3.493 \%$ & $0.398 \%$ & $2.357 \%$ \\
\hline SPREAD1 & $-2.457 \%$ & $0.620 \%$ & $-1.101 \%$ & $0.559 \%$ \\
\hline STT3M & $0.078 \%$ & $0.058 \%$ & $1.197 \%$ & $0.782 \%$ \\
\hline RRFRI & $-1.508 \%$ & $3.561 \%$ & $-0.774 \%$ & $2.410 \%$ \\
\hline USPCE & 11029.96 & 817.193 & 13515.86 & 601.894 \\
\hline LUSPCE & 9.306 & 0.074 & 9.511 & 0.045 \\
\hline GUSPCE & $3.407 \%$ & $3.907 \%$ & $4.239 \%$ & $3.377 \%$ \\
\hline GUSRPCE & $1.821 \%$ & $3.788 \%$ & $2.315 \%$ & $3.248 \%$ \\
\hline GAP1 & $-3.279 \%$ & $3.913 \%$ & $-2.998 \%$ & $3.466 \%$ \\
\hline USDJIA & 13361.00 & 3104.75 & 22333.65 & 3385.526 \\
\hline LUSDJIA & 9.471 & 0.247 & 10.002 & 0.157 \\
\hline GUSDJIA & $9.952 \%$ & $55.692 \%$ & 11.348 & 43.261 \\
\hline USRDJIA & 5835.631 & 1166.922 & 9028.39 & 1183.614 \\
\hline LUSRDJIA & 8.651 & 0.211 & 9.099 & 0.135 \\
\hline GUSRDJIA & $8.366 \%$ & $55.666 \%$ & $9.378 \%$ & $43.183 \%$ \\
\hline USRGDP2012 & 16207.12 & 709.469 & 18199.55 & 491.977 \\
\hline LUSRGDP2012 & 9.692 & 0.044 & 9.809 & 0.027 \\
\hline GUSRGDP2012 & $1.857 \%$ & $4.532 \%$ & $2.400 \%$ & $3.689 \%$ \\
\hline USU & $7.838 \%$ & $1.544 \%$ & $4.286 \%$ & $0.472 \%$ \\
\hline USPSR & $5.279 \%$ & $1.181 \%$ & $7.298 \%$ & $0.644 \%$ \\
\hline RPUS10YTB (Risk) & $2.508 \%$ & $0.606 \%$ & $1.200 \%$ & $0.524 \%$ \\
\hline
\end{tabular}

Note: USFFR = U.S. effective federal funds rate, USRFFR = U.S. real effective federal funds rate, USMB = U.S. monetary base, LUSMB = ln of U.S. monetary base, GUSMB = growth of U.S. monetary base, M2 = money supply (M2), LUSM2 = ln of money supply (M2), GUSM2 = growth of money supply (M2), USCPI = U.S. consumer price index, LUSCPI = ln of USCPI, USINF = U.S. inflation rate, US10YTB = U.S. 10-year Treasury bonds rate, USR10YTB = U.S. real 10-year Treasury bonds rate, SPREAD1 = spread between the effective federal funds rate and the yield on 10-year Treasury bonds (normal, positive; flat; inverted yield curve, negative), STT3M= short-term Treasury bill 3-month maturity, RRFRI $=$ real risk-free rate of interest $\left(i_{R F}-\pi\right)$, USPCE $=$ U.S. personal consumption expenditures, LUSPCE $=\ln$ of USPCE, GUSPCE $=$ growth of 
the USPCE, GUSRPCE = growth of the U.S. real PCE, GAP1 = the gap between the real effective federal funds rate and the growth of the real PCE (=USRFFR-GUSRPCE), USDJIA = the U.S. Dow Jones Industrial Average, LUSDJIA = ln of the DJIA, GUSDJIA = growth of the DJIA, USRDJIA = U.S. real DJIA, LUSRDJIA = ln of the real DJIA, GUSRDJIA = growth of the real DJIA, USRGDP2012 = U.S. real GDP (2012 base year), LUSRGDP2012 = ln of the U.S. real GDP (2012 base year), GUSRGDP2012 = growth of the U.S. real GDP (2012 base year), USU = U.S. unemployment rate, USPSR = U.S. personal savings rate, RPUS10YTB $=$ risk premium on 10-year Treasury bonds (=US10YTB-STT3M), $\bar{R}=$ the average value of the variable, and $\sigma_{R}=$ the standard deviation of the variable.

Source: Economagic.com and Yahoo/Finance

Table A2

Vector Autoregression Estimates (ZIRR, 2008:12-2015:11)

\begin{tabular}{|c|c|c|c|c|c|}
\hline Variables & $d_{j i a_{t}}$ & $r g d p_{t}$ & $i_{10 Y T B_{t}}$ & $p_{t}$ & $u_{t}$ \\
\hline \multirow[t]{2}{*}{$d_{j i a_{t-1}}$} & $0.678^{* * *}$ & -0.002 & 0.823 & $0.016^{* *}$ & 0.347 \\
\hline & $(0.119)$ & $(0.011)$ & $(0.554)$ & $(0.008)$ & $(0.357)$ \\
\hline \multirow[t]{2}{*}{$d_{j i a_{t-2}}$} & $-0.206^{*}$ & -0.001 & -0.640 & 0.001 & $-0.723^{* *}$ \\
\hline & $(0.117)$ & $(0.011)$ & $(0.542)$ & $(0.007)$ & $(0.350)$ \\
\hline \multirow{2}{*}{$r g d p_{t-1}$} & 0.604 & $0.660^{* * *}$ & -5.781 & -0.034 & -3.833 \\
\hline & (1.305) & $(0.119)$ & $(6.044)$ & $(0.083)$ & $(3.895)$ \\
\hline \multirow[t]{2}{*}{$r g d p_{t-2}$} & 1.505 & 0.121 & $11.026^{*}$ & -0.038 & $-6.948^{*}$ \\
\hline & $(1.364)$ & $(0.124)$ & $(6.319)$ & $(0.087)$ & $(4.072)$ \\
\hline \multirow{2}{*}{$i_{10 Y T B_{t-1}}$} & 0.021 & 0.002 & $0.990^{* * *}$ & -0.001 & $-0.233^{* * *}$ \\
\hline & $(0.024)$ & $(0.002)$ & $(0.110)$ & $(0.002)$ & $(0.071)$ \\
\hline \multirow{2}{*}{$i_{10 Y T B_{t-2}}$} & -0.005 & -0.002 & $-0.211^{*}$ & -0.001 & $0.176^{* *}$ \\
\hline & $(0.026)$ & $(0.002)$ & $(0.119)$ & $(0.002)$ & $(0.077)$ \\
\hline \multirow{2}{*}{$p_{t-1}$} & -1.393 & 0.096 & 0.891 & $1.074^{* * *}$ & $8.692^{*}$ \\
\hline & (1.728) & $(0.157)$ & $(8.005)$ & $(0.110)$ & $(5.158)$ \\
\hline \multirow[t]{2}{*}{$p_{t-2}$} & 1.615 & -0.023 & $-17.882^{* * *}$ & $-0.307^{* * *}$ & -5.925 \\
\hline & (1.579) & $(0.144)$ & $(7.315)$ & $(0.101)$ & $(4.714)$ \\
\hline \multirow[t]{2}{*}{$u_{t-1}$} & 0.024 & 0.001 & $0.382^{* * *}$ & 0.001 & $0.659^{* * *}$ \\
\hline & $(0.035)$ & $(0.003)$ & $(0.163)$ & $(0.002)$ & $(0.105)$ \\
\hline \multirow[t]{2}{*}{$u_{t-2}$} & 0.017 & 0.001 & $-0.260^{*}$ & -0.001 & 0.117 \\
\hline & $(0.031)$ & $(0.003)$ & $(0.146)$ & $(0.002)$ & $(0.093)$ \\
\hline \multirow[t]{2}{*}{$c_{0}$} & $-21.567^{* *}$ & 1.334 & 15.625 & $1.503^{* *}$ & $100.804^{* * *}$ \\
\hline & $(9.876)$ & $(0.899)$ & $(45.755)$ & $(0.630)$ & $(29.484)$ \\
\hline \multirow[t]{2}{*}{$i_{F F_{t}}^{e f f}$} & -0.102 & 0.035 & -0.989 & -0.006 & $1.963^{* * *}$ \\
\hline & $(0.262)$ & $(0.024)$ & $(1.214)$ & $(0.017)$ & $(0.782)$ \\
\hline \multirow[t]{2}{*}{$m b_{t}$} & 0.102 & 0.021 & 0.641 & 0.013 & $0.952^{*}$ \\
\hline & $(0.178)$ & $(0.016)$ & $(0.826)$ & $(0.011)$ & $(0.532)$ \\
\hline \multirow[t]{2}{*}{$m_{t}$} & 0.422 & 0.026 & 2.056 & 0.021 & -1.552 \\
\hline & $(0.419)$ & $(0.038)$ & (1.943) & $(0.027)$ & $(1.252)$ \\
\hline$R^{2}$ & 0.976 & 0.994 & 0.920 & 0.996 & 0.995 \\
\hline SEE & 0.042 & 0.004 & 0.193 & 0.003 & 0.125 \\
\hline$F$ & 218.563 & 807.381 & 61.995 & 1263.581 & 975.740 \\
\hline$N$ & 84 & 84 & 84 & 84 & 84 \\
\hline
\end{tabular}


Note: $d j i a_{t}=$ USDJIA= U.S. Dow Jones Industrial Average Index, $r g d p_{t}=$ USRGDP2009= U.S. real GDP, $i_{10 Y T B_{t}}=$ US10YTB= U.S 10-Year Treasury Bonds Rate, $p_{t}=$ LUSCPI $=\ln$ of U.S. CPI, $u_{t}=$ USU $=$ U.S. unemployment rate, $c_{0}=$ constant term, $i_{F F_{t}}^{e f f}=$ USFFR $=$ U.S. effective federal funds rate, $m b_{t}=$ LUSMB $=$ ln of U.S. monetary base, $m_{t}=$ LUSM2 $=\ln$ of U.S. money supply (M2), ${ }^{* * *}=$ significant at the $1 \%$ level, ${ }^{* *}=$ significant at the $5 \%$ level, ${ }^{*}=$ significant at the $10 \%$ level, $R^{2}=$ R-squared, $S E E=$ S.E. equation, $F=$ F-statistic, and $N=$ number of observations.

Source: See, Table 1.

Table A3

Vector Autoregression Estimates (NR, 2015:12-2019:06)

\begin{tabular}{|c|c|c|c|c|c|}
\hline Variables & djia $_{t}$ & $r g d p_{t}$ & $i_{10 Y T B_{t}}$ & $p_{t}$ & $u_{t}$ \\
\hline \multirow[t]{2}{*}{$\operatorname{djia}_{t-1}$} & $0.539^{* * *}$ & $0.023^{* * *}$ & $1.308^{*}$ & $0.014^{*}$ & $-0.863^{*}$ \\
\hline & $(0.175)$ & $(0.010)$ & $(0.793)$ & $(0.009)$ & $(0.568)$ \\
\hline \multirow[t]{2}{*}{ djia $_{t-2}$} & -0.096 & -0.010 & -0.676 & 0.012 & -0.535 \\
\hline & $(0.209)$ & $(0.012)$ & $(0.947)$ & $(0.011)$ & $(0.678)$ \\
\hline \multirow[t]{2}{*}{$r g d p_{t-1}$} & -1.495 & 0.004 & -8.300 & 0.007 & -5.796 \\
\hline & (2.259) & $(0.133)$ & $(10.232)$ & $(0.116)$ & $(7.326)$ \\
\hline \multirow[t]{2}{*}{$r g d p_{t-2}$} & $5.613^{* *}$ & $-0.295^{*}$ & -12.502 & 0.062 & 8.565 \\
\hline & $(2.546)$ & $(0.150)$ & (11.529) & $(0.131)$ & $(8.255)$ \\
\hline \multirow{2}{*}{$i_{10 Y T B_{t-1}}$} & -0.025 & $-0.006^{* *}$ & $1.043^{* * *}$ & $0.004^{* *}$ & 0.190 \\
\hline & $(0.042)$ & $(0.002)$ & $(0.190)$ & $(0.002)$ & $(0.139)$ \\
\hline \multirow{2}{*}{$i_{10 Y T B_{t-2}}$} & 0.059 & -0.002 & -0.266 & $-0.005^{* *}$ & $-0.264^{*}$ \\
\hline & $(0.049)$ & $(0.003)$ & $(0.223)$ & $(0.003)$ & (0.159) \\
\hline \multirow[t]{2}{*}{$p_{t-1}$} & 0.128 & $0.386^{*}$ & 27.520 & $0.759^{* * *}$ & -10.426 \\
\hline & (3.933) & $(0.232)$ & (17.814) & $(0.203)$ & (12.754) \\
\hline \multirow[t]{2}{*}{$p_{t-2}$} & -1.085 & 0.016 & -15.479 & -0.239 & 10.432 \\
\hline & (3.439) & $(0.203)$ & (15.576) & $(0.177)$ & (11.152) \\
\hline \multirow[t]{2}{*}{$u_{t-1}$} & -0.006 & 0.001 & -0.082 & 0.004 & $0.463^{* *}$ \\
\hline & $(0.055)$ & $(0.003)$ & $(0.248)$ & $(0.003)$ & $(0.177)$ \\
\hline \multirow[t]{2}{*}{$u_{t-2}$} & -0.001 & -0.003 & 0.218 & -0.001 & $-0.314^{*}$ \\
\hline & $(0.052)$ & $(0.003)$ & $(0.235)$ & $(0.003)$ & $(0.168)$ \\
\hline \multirow[t]{2}{*}{$c_{0}$} & $-49.232^{*}$ & $9.958^{* * *}$ & 117.144 & 1.063 & 6.268 \\
\hline & $(28.715)$ & (1.694) & $(130.056)$ & (1.479) & (93.117) \\
\hline \multirow[t]{2}{*}{$i_{F F_{t}}^{e f f}$} & -0.108 & $0.028^{* * *}$ & 0.298 & 0.004 & -0.178 \\
\hline & $(0.091)$ & $(0.005)$ & $(0.412)$ & $(0.005)$ & $(0.295)$ \\
\hline \multirow[t]{2}{*}{$m b_{t}$} & $0.501^{*}$ & $-0.035^{* *}$ & -0.215 & -0.014 & 0.018 \\
\hline & $(0.284)$ & $(0.017)$ & (1.285) & $(0.015)$ & $(0.920)$ \\
\hline \multirow[t]{2}{*}{$m_{t}$} & $1.646^{* * *}$ & $0.068^{*}$ & 1.630 & $0.078^{* *}$ & -1.634 \\
\hline & $(0.681)$ & $(0.040)$ & (3.083) & $(0.035)$ & (2.208) \\
\hline$R^{2}$ & 0.973 & 0.997 & 0.934 & 0.997 & 0.969 \\
\hline SEE & 0.031 & 0.002 & 0.139 & 0.002 & 0.099 \\
\hline$F$ & 81.174 & 715.492 & 31.505 & 657.447 & 69.508 \\
\hline$N$ & 43 & 43 & 43 & 43 & 43 \\
\hline
\end{tabular}

Note: See, Tables 1 and 2. 